\title{
Evaluation of some proximal sensing methods for mapping soils in urbanized terrain,
}

\section{Detroit, Michigan, USA}

\author{
Jeffrey L. Howard*, Katharine M. Orlicki, Sarah M. LeTarte
}

Department of Geology, Wayne State University, Detroit, Michigan 48202, United States

\section{Abstract}

A study was carried out to test the accuracy and utility of field probes as proximal sensing tools for sitespecific and regional soil mapping in the heavily urbanized terrain of Detroit, MI, USA. The results suggest that surface scanning in situ with a magnetic susceptibility (MS) field probe is accurate, but limited by tall grass. Better results were obtained after removal of the turf layer. The accuracy of the electrical conductivity (EC) field probe was questionable. Hence, superior results were obtained ex situ using both EC and MS lab sensors. Lab EC and MS were well suited for regional soil mapping, whereas all of the methods provided at least some useful information for sitespecific applications. Tall grass, excessive artifact content, and severe compaction were the greatest limitations of proximal sensing. Tall grass interfered with surface scanners (MS; metal detector), whereas excessive artifacts and compaction restricted use of the EC surface probe. Penetrability and $\mathrm{pH}$ were useful for discriminating between natural and anthropogenic soils, and moisture content for proximal sensing of soil $\wedge$ A horizons. MS was especially useful for delineating soils impacted by fly ash. Although it is less rapid and more labour-intensive than field methods, the lab-based approach still provides a minimally invasive alternative to augering. Lab-based geophysical surveying can be carried out first, and the results used as a guide for an auger-based soil survey. An anthropogenic map index (AMI) is introduced which combines $\mathrm{pH}$, penetrability, EC and MS into a single overall measure of soil quality. AMI-based maps are postulated to be a useful as a geographic representation of soil health. These results support our hypothesis that proximal sensing methods can facilitate soil mapping in urbanized terrain based on the degree of human disturbance, and differences in artifact assemblages related to land use history.

Key words: urban soil; technosol; proximal sensing; magnetic susceptibility; electrical conductivity

\section{${ }^{*}$ Corresponding author.}

E-mail address: (313-577-3258); jhoward@wayne.edu (J.L. Howard)

\section{Introduction}

C) 2016. This manuscript version is made available under the Elsevier user license http://www.elsevier.com/open-access/userlicense/1.0/ 
Remote sensing methods are based on the fact that features on the Earth's surface reflect or emit electromagnetic radiation with different and sometimes highly specific reflectance spectra. Airborne and spacebased approaches could potentially facilitate regional soil mapping, but they are ineffective where soils lie beneath a masking cover of vegetation, pavement, or other objects. Remote sensing methods also suffer from errors caused by spectral confusions (e.g., different materials emitting similar spectra), and atmospheric scattering (Obade and Lal, 2013; Obade et al., 2013). Proximal sensing techniques are more accurate and involve measurements collected from close by, or within, the soil. The data collection process may be in situ (field-based) or ex situ (lab-based), noninvasive or invasive, and stationary or mobile (Viscarra et al., 2010, 2011). Proximal sensing relies on such field methods as ground-penetrating radar, electrical resistivity or conductivity, magnetic susceptibility, penetrability, xray fluorescence, electromagnetic induction, and others (Hartemink and Minasny (2014). All are able to probe more or less into the subsurface. The equipment used includes non-invasive, hand- or machine-held sensors and surface scanners, and minimally invasive pointed surface probes which are inserted into the shallow surface soil. Proximal sensing and near-surface geophysical methods have been used for many years to analyze patterns in the geospatial distribution of soils, but usually on a small scale ( $\leq 1 \mathrm{ha}$ ). The utility of proximal sensing methods for agricultural, geotechnical, archaeological, and mine-related surveys is well established (Eriksen, 2011; Reynolds, 2011; Nearing et al., 2013; Obade et al., 2013; Hartemink and Minasny, 2014; Doolittle and Brevik, 2014; Kapper et al., 2014). Soil magnetic susceptibility has also been used widely to map pollution in urban soils (Vodyanitskii and Shoba, 2015; Magiera et al., 2015), but further evaluation of proximal sensing methods for regional soil mapping in urbanized terrain is needed.

In a previous topographic quadrangle study, we found evidence suggesting that anthropogenic surficial deposits in Detroit, Michigan, USA (Fig. 1), could be delineated geographically on the basis of unique artifact assemblages related to differences in land use history (Howard et al., 2013a). The results of another study showed that anthropogenic surficial deposits and their artifact assemblages could be mapped, even on the scale of a single vacant lot, using the hand-auger approach and a grid of closely spaced sampling points (Howard et al., 2015; 53 Howard and Shuster, 2015). However, the method was too labour-intensive for routine application. In subsequent 54 studies, we found that the electrical conductivity (EC) and magnetic susceptibility (MS) signatures of soils in Detroit were significantly impacted by different types of artifacts and microartifacts. There were systematic relationships 
between soil geophysical properties, microartifacts and land use history (Howard and Orlicki, 2015, 2016). However, these studies were based entirely on laboratory measurements.

The purpose of this study was to field-test the hypothesis that proximal sensing methods can facilitate soil mapping in urbanized terrain based on the degree of human disturbance and differences in land use history. This is important to know because increasing anthropogenic impact tends to limit the suitability of vacant land for repurposing as green infrastructure and urban agriculture (USEPA, 2011). The objectives of the study were twofold: 1) evaluate the accuracy of field-probe measurements of EC and MS, and 2) evaluate the utility of various field- and lab-based methods for general use as proximal sensing tools. Accuracy was tested by comparing field data with laboratory measurements, and auger-based ground truth. The utility of geophysical and electrochemical measurements (MS, EC, penetrability, moisture content, temperature and $\mathrm{pH}$ ) as proximal sensing tools was tested along transects across different land use types, and then through detailed mapping of a city block-sized parcel of vacant land produced by building demolition. Regional-scale geophysical maps of Detroit city were also produced using proximal sensing methods, and compared with a surficial geologic map based on soil test borings.

\section{Materials and methods}

\subsection{Terminology}

Radiocarbon dates were converted to calendar (cal) years before present (1950) using the method of Fairbanks et al. (2005). “Anthropogenic particles” are artifacts of any size (Howard and Orlicki, 2016), whereas the terms "artifact" and "macroartifact" are used interchangeably for any object $>2 \mathrm{~mm}$ in size that was produced, modified, or transported from its source by human activity (Dunnell and Stein, 1989; IUSS Working Group, 2006; Schoeneberger et al., 2012; Soil Survey Staff, 2014). “Microartifacts” are 0.25 to $2.0 \mathrm{~mm}$ in size (Dunnell and Stein, 1989; Rosen, 1991; Sherwood, 2001), and “microparticles” are < 0.25 mm in size. Human-altered material (HAM) is defined as parent material for a soil that has undergone in situ mixing or disturbance by humans. Humantransported material (HTM) is defined as parent material for a soil that has been moved horizontally onto a pedon from a source outside of that pedon by human activity, usually with the aid of earthmoving equipment (Soil Survey Staff, 2014). Hence, an anthropogenic soil is defined as one that has formed either in HAM or HTM. An anthropogenic surficial geological unit is a morphostratigraphic unit of anthropogenic origin defined on the basis of lithology (artifact assemblages), land use history, type of site and soil type. This definition is consistent with the anthrostratigraphic unit concept of Howard (2014). 


\subsection{Geological Setting}

Detroit is located in southeastern Michigan across the Detroit River from Windsor, Ontario, Canada (Fig. 1). Geological maps that pre-date urbanization (Leverett and Taylor, 1915; Sherzer, 1916) show that the city was built on a low lying plain (Detroit lowland) characterized by glacial landforms. The Detroit lowland is underlain by Paleozoic sedimentary bedrock capped with $35 \mathrm{~m}$ of clayey diamicton deposited during the late Pleistocene, mainly as basal till. However, the uppermost $\sim 6 \mathrm{~m}$ to $10 \mathrm{~m}$ was deposited by subaqueous mass flow in glacial Lake Maumee 16,343 cal yr BP (Howard, 2010). This “waterlaid till” deposit thickens beneath a low-lying, southeasttrending swell (Detroit moraine) that was formed as a subaqueous end moraine (Fig. 1). The "till-floored" lake plain of Lake Maumee was subsequently reworked by lacustrine wave action along the margins of paleolakes Wayne, Grassmere and Elkton 14,785 to 14,290 cal yr BP (Calkin and Feenstra, 1985). Hence, the ground surface beneath Detroit was originally very swampy (underlain by clayey diamicton), with well drained uplands formed on a discontinuous cappings of gravelly sand and rhythmite $1 \mathrm{~m}$ to $8 \mathrm{~m}$ thick (Howard, 2010). Locally, lacustrine and deltaic sediments in eastern and southwestern Detroit were deposited in paleolakes St. Clair and Rouge between 14,290 to 5,728 cal yr BP (Raphael and Jaworski, 1982; Herdendorf and Bailey, 1989; Kincare and Larson, 2009). These lake phases were brought to an end as the Detroit River was formed by outburst flooding across the Detroit moraine (Howard, 2015). Detroit has a cool humid-temperate (udic-mesic) climate, with a mean annual temperature of $9^{\circ} \mathrm{C}\left(49^{\circ} \mathrm{F}\right), 99 \mathrm{~cm} \mathrm{yr}^{-1}$ of precipitation, and a frost line at $\sim 1 \mathrm{~m}$ below ground level. The natural landscape is characterized by mixed deciduous forest, whereas grass predominates in urbanized areas. Maximum local relief is 73 $\mathrm{m}$, and the area has been artificially drained since the 1830s. Natural soils (Larson, 1977) on the lakebed plains beneath Detroit include the Blount series (Aeric Epiaqualf), Metamora series (Udollic Epiaqualf), Pewamo series (Typic Argiaquoll), and Selfridge series (Aquic Arenic Hapludalf, loamy, mixed, mesic).

The urbanized land lying beneath Detroit is comprised almost entirely of anthropogenic surficial deposits of mixed earthy fill in which artifacts are widespread (Howard and Olszewska, 2011; Howard et al., 2013b). Extensive areas of industrial land were, and still are, concentrated along the riverfront and railroad lines, and small areas of park and cemetery land are scattered throughout the city. Detroit is mostly residential land (including schools, churches and small commercial businesses), which has been the target of urban redevelopment since the 1960s. So many buildings ( $>150,000$ ) have been demolished that $\sim 30 \%$ of the city is now vacant land. Most of 
this demolition has taken place lot-by-lot, hence the landscape is a mosaic of occupied buildings, abandoned derelict buildings, and vacant lots created by building demolition. Many vacant lots have escaped redevelopment for decades, during which time the fill was affected by natural and human-altered soil-forming processes. These anthropogenic soils are classified primarily as Anthropic or Anthroportic Udorthents, according to Soil Taxonomy (Soil Survey Staff, 2014), or as Technosols using the World Reference Base (IUSS Working Group, 2006). ^Au horizons have formed within about $25 \pm 5$ years, and weathering of calcareous and ferruginous artifacts has resulted in measurable increases in carbonate and Fe-oxides, respectively after more than 35 years (Howard and Olszewska, 2011; Howard et al., 2013b). Left alone, the bare land surface produced by demolition and backfilling is typically revegetated within a few years, mainly by invasive plant species.

\subsection{Field Survey}

Soil properties measured by proximal sensing methods included MS, EC, moisture content, soil temperature, and penetrability. MS was measured with a Bartington MS2D surface scanner. Although we did compare results with and without the sod layer, previous work had showed that better results were obtained by removing the surface turf layer (Schmidt et al., 2005; Zawadzki et al., 2010). Hence, magnetic susceptibility was measured mainly on the soil surface at $3 \mathrm{~cm}$ depth after turf removal. EC, moisture content, and soil temperature were measured by inserting the pointed probe of an AquaTerr EC-350 salinity multimeter to a depth of 15 to $20 \mathrm{~cm}$. Penetrability is a measure of the resistance of a soil to vertical penetration, and is commonly used to quantify soil compaction (Bradford, 1986; Miller et al., 2001). This was measured by pushing the pointed probe of a handoperated Dickey-john cone penetrometer to a depth of $35 \mathrm{~cm}$, and averaging three measurements spaced $1 \mathrm{~m}$ apart. We also tested electromagnetic induction by ground surface scanning with a Garrett ACE350 metal detector. Several field probes failed temporarily during the course of the study.

The field survey was carried out after subdividing the study area informally into four quadrants (NW, SW, NE and SE). The utility of proximal sensing for site-specific work was tested by way of transects made across different land use types (parkland, residential demolition, undemolished residential, industrial) in three different quadrants (Fig. 2; Table 1). Each transect was 5 to $6 \mathrm{~km}$ in length, and comprised of 27 to 30 sampling sites spaced $125 \mathrm{~m}$ to $150 \mathrm{~m}$ apart. Another site-specific test was done by way of detailed mapping of a 1.5 ha tract of vacant urban land produced by building demolition in the NE quadrant (Fig. 2). This site was mapped at 1:1800 scale using 75 sampling points comprising a $10 \mathrm{~m}$ x $20 \mathrm{~m}$ grid. The utility of proximal sensing for regional mapping was 
evaluated by producing MS- and EC-based geophysical maps of Detroit city. This was done by collecting data at 138 locations scattered across the city, evenly split between demolished and undemolished residential sites. The measurements described above were collected at each sampling site, and GPS coordinates were collected using a Garmin III plus instrument. Soil profile descriptions (color, texture, artifact content, reaction) were collected to the depth of auger refusal, or to a depth of 30 to $50 \mathrm{~cm}$ with a hand auger $(3.5 \mathrm{~cm}$ diameter bucket) using standard NRCS methods (Schoeneberger et al., 2012). A total of 297 one kg samples of surface layer soil were collected to a depth of $15 \mathrm{~cm}$ in clean polypropylene bags, returned to the lab, and stored at $4^{\circ} \mathrm{C}$ until analysis. The anthropogenic surficial geological map of Detroit city (1:180,000 scale) was produced from 1:24,000 scale USGS topographic maps, using the 138 soil borings collected in this study, and several hundred collected previously (Howard et al., 2013). Land use and geomorphic history was ascertained with the aid of Lidar and digital elevation map imagery, historic USGS topographic maps, Sanborn maps, and other historic records.

\subsection{Lab and Data Analysis}

The accuracy of field MS and EC measurements was evaluated by comparison with laboratory measurements. Soil samples ( $1 \mathrm{~kg})$ were collected from all of the sites at 3 to $15 \mathrm{~cm}$ depth, placed in clean polypropylene bags, and stored at $4^{\circ} \mathrm{C}$ until analysis. Soils were air-dried for $>4$ days and hand-sieved to obtain the $<2 \mathrm{~mm}$ fraction. Electrical conductivity and $\mathrm{pH}$ were measured using $10 \mathrm{~g}$ of soil $(<2 \mathrm{~mm})$ and $20 \mathrm{ml}$ of d/d water. The samples were stirred periodically for 5 minutes and then allowed to stand overnight. EC was measured using the supernatant, and a Mettler Toledo S230 conductivity meter, following the recommendations of Santini et al. (2013). The $\mathrm{pH}$ of the supernatant liquid was measured using a Mettler Toledo FEP 20 pH meter. Magnetic

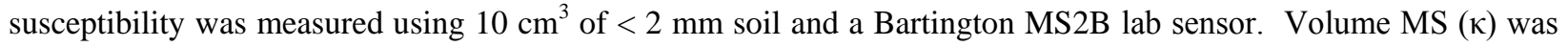
converted to mass MS $(\chi)$ according to the guidelines provided by the manufacturer. Statistical tests showed that electrical conductivity and penetrability data were normally distributed. Magnetic susceptibility data followed a lognormal distribution, as reported previously (Gladysheva et al., 2007). Thus, EC and penetrability data are tabulated as arithmetic means and MS data as geometric means. Student's $t$-test was used to test the statistical significance of variations in soil EC and penetrability as a function of land use type using standard methods (Davis, 1986). Magnetic susceptibility data were tested using the same methods after lognormal transformation. Geophysical maps were generated using Surfer 11.4.958 (Golden Software Co.). They represent interpolated continuous data 
168

169

170

171

172

173

174

175

176

177

178

179

180

181

182

183

184

185

186

187

188

189

190

191

192

193

194

195

across the map areas, and were generated using a linear variogram. The grid report provided the univariate statistics. Both inverse distance weighting (IDW) and kriging methods were tested. After multiple trials and observations, IDW was selected as the interpolation method. Isopleth maps were then overlaid onto aerial photographs and Google Earth maps to further interpret the significance of geophysical anomalies.

\section{Results}

\subsection{Anthropogenic Surficial Geological Map}

The auger-based geologic map of anthropogenic surficial deposits in Detroit is shown in Figure 2. Five basic units were delineated (Table 1), based on Detroit's historic settlement pattern and land use history. Manufactured Land (QaM) was underlain by a manufactured layer, i.e. an artificial impervious barrier (brick, concrete, asphalt, etc.) comprised of human-manufactured material (Soil Survey Staff, 2014). This map unit comprised the innermost and oldest part of the city (Farmer, 1890), and was characterized by a mixed landscape of occupied and unoccupied, derelict skyscrapers. The land surface of $18^{\text {th }}$ century Detroit (founded 1701) lies beneath the manufactured ground surface of this map unit. Residential Land in Zone 1 (QaR1) was characterized by strong human disturbance, and was underlain by multicyclic fill (produced by multiple demolition cycles), whereas Zone 2 (QaR2) was underlain by relatively weakly disturbed natural soils, and monocyclic fill. The boundary between Zone 1 and 2 was transitional, but corresponds to the Detroit City limits circa $1910 \pm 10$ yrs (Doxiadis, 1967). This boundary was approximated on the ground by a change from an older northwest-trending street pattern (inherited from French ribbon farms), to a younger north-south-trending (Jeffersonian) configuration (Fig. 2). Anthropogenic soils in Zones 1 and 2 generally contain abundant $19^{\text {th }}$ century and $20^{\text {th }}$ century artifacts, respectively. Industrial Land (QaI) was located primarily along major railroad lines, and includes airports, marinas and river dredgings. Industrial Land was mainly concentrated along the riverfront during the late $19^{\text {th }}$ century, and involved iron smelting and other processes utilizing coal as a fuel source (Roock, 1964). Intensive development related to the early car industry caused Industrial Land to expand rapidly along major railroad lines (e.g., Grand Trunk Railroad) during the early $20^{\text {th }}$ century (Davidson, 1953; Sinclair 1972; Hyde, 1980, 2001). Cemetery Land (QaC) and Park Land (QaP) were usually small areas up to several hectares in size scattered across the map area. Cemeteries, sometimes dating back to the early $19^{\text {th }}$ century, were generally underlain by human-altered and human-transported materials. Park Land was mainly undisturbed grassland underlain by natural soils (woodland is very scarce). Signs of human disturbance are sometimes common, and some parks are located on former demolition sites. 


\subsection{Soil Transects}

There was good agreement overall between field (MSf) and lab (MSx) magnetic susceptibility data collected from transects (Appendix Table1), although analyses with the lab sensor usually produced higher values. In some cases, there were very large discrepancies, either with values obtained in the lab or field being anomalously high. This usually involved demolition sites, hence these anomalies are attributed to the irregular distribution of ferruginous artifacts such as nails. A very highly significant positive statistical linear correlation $(\mathrm{r}=0.79 ; p=$ 0.005) between MSx and MSf was obtained using a pooled dataset in which these few (<10\%) spurious measurements were removed (Fig. 3A). The results suggest that field probes can be used to accurately assess MS. Presumably the surface probe could be used to survey without removing the turf layer, but we found that above-turf MSf signals were much weaker than those obtained with the sod removed. Tall grass usually precluded the use of the surface probe on vacant and abandoned properties, hence it was not possible to make a MS field survey in Detroit unless the turf was first removed. A highly significant positive statistical linear correlation $(\mathrm{r}=0.63$; $p=$ 0.005) was also observed between penetrability and MSf (Fig. 3B). This is attributed to a greater mass of magnetic minerals per unit volume of soil with increasing bulk density. The metal detector appeared to be useful for detecting subsurface debris at demolition sites, but tall grass restricted its use.

There was a poor correlation between field (ECf) and lab (ECx) electrical conductivity, but a highly significant negative linear correlation ( $\mathrm{r}=-0.86 ; p=0.005)$ between ECf and moisture content (Fig. 3C). There was also a statistically significant negative correlation between penetrability and moisture content $(\mathrm{r}=-0.44 ; p=0.05)$, which is similar to that seen in previous studies (Miller et al., 2001). Soil temperature showed a strong correlation with air temperature, i.e. topsoil temperature increased $3^{\circ}$ to $4^{\circ} \mathrm{C}$ during the daily course of each transect (Fig. 3D). This is typical of soil temperatures in the shallow subsurface (Brevik et al., 2004), but precluded a meaningful evaluation of anthropogenic effects on soil temperature. The highest MSf values were generally obtained on industrial site soils

(Fig. 4A). Demolition site soils were also found to have relatively high values of MS, EC and penetrability, compared with those at park and undemolished residential sites (Fig. 4B, C and D). Soil borings showed that some parkland soils were moderately disturbed, and this is reflected in systematic variations in MS and penetrability in parks 1 and 2 (Fig. 4B and D). The increased MSf signal in disturbed soils is attributed to compaction, as indicated by the positive correlation with penetrability noted above. 
There was no statistically significant difference between the mean values (Table 2) of MSf at undisturbed park and undemolished residential site soils (Table 3). In contrast, there were highly significant differences between these and residential demolition and industrial site soils, which were 2 to 5 times greater. These relationships are consistent with observations in the field that undemolished residential sites had HAM-like soils, whereas HTM-type soils were characteristic of demolition and industrial sites. MSx values showed similar relationships, but the mean value for undemolished residential sites was elevated and similar to that of demolition sites. This is attributed to the fact that transect 2 soils were impacted by highly magnetic fly ash microparticles (Howard and Orlicki, 2015). No statistically significant difference was seen when a similar comparison was made using transect 1 where soils were not impacted. The mean values of EC for the anthropogenic soils were generally twice those of undisturbed parkland soils (Table 2). These differences are also statistically significant (Table 3), although this could not be demonstrated for demolition site soils because of their high variance. Mean values of penetrability support the interpretation that undemolished residential site soils are HAM-like and similar to soils at undisturbed parkland sites. Demolition and industrial site HTM-type soils had penetration values twice as high as those at relatively undisturbed sites. Appendix Table 1 shows that the $\mathrm{pH}$ values of anthropogenic soils were generally $>7.0$, whereas those of natural soils were less. Elevated pH levels are attributed to the presence of calcareous artifacts or to backfilling with calcareous glacial sediments.

\subsection{Detailed mapping}

The 1.5 ha (3.6 ac) site mapped in detail (scale $=1: 1800$ ) was part of a larger 40 ha parcel of vacant urban land (Fig. 5A) created by the demolition of 500 buildings as part of Detroit’s failed 1996 plan to expand the Coleman A. Young Airport (MacDonald, 2007). The buildings were mainly single family homes built during the early automobile industry boom of the 1920s. Aerial photographs show that the area was still completely covered by many closely spaced homes in 1981, but hundreds had been demolished by 1997 . The map site was covered by two rows of homes, each on a rectangular lot fronting Elgin and Montlieu Streets, with an alley at the back. The homes were typically situated close to the street, and had a large back yard and a garage on the alley. Aerial photographs show that by 1997, the alley and most of the homes on Elgin St. were demolished. The demolition sites from 1997 were overgrown with vegetation by 2005, and numerous trees had become established along the former alleyway. The remaining homes, including nine on Montlieu St., were demolished between 2010 and 2014. The 
area was originally underlain by the somewhat poorly drained Selfridge series (Soil Survey Staff, 2015; pers. comm.).

By the time our sampling occurred in 2015 (Fig. 5B), all that remained of the former neighborhood were the sidewalks, the ruins of several burned out homes, and a garage (Figs. 6A and 7A). Large trees (probably dating from 1997) were growing out of piles of concrete rubble in the southwestern corner of the map site. Soil borings (Appendix Table 2) showed that most of the site was covered in clayey soils, with a patch of sandy soils in the central part. The former locations of several homes could be identified by sunken ground. Artifacts were most abundant near Elgin and Montlieu Streets, and were primarily brick, mortar, concrete, nails, wood, coal and coal cinders, similar to those seen at the site previously studied on Wisner St. (Howard and Shuster, 2015) and elsewhere in Detroit (Howard et al., 2013b, 2015).

The map of soil moisture content (Fig. 6B) shows a relatively distinct north-south zonation. The areas of highest moisture content (in the northwest and northeast) correspond to places that underwent demolition in 1997. These areas now have soils with $\wedge$ Au horizons, which are absent at the recently demolished sites along Montlieu Street. Hence, spatial variations are explained qualitatively by differences in water-holding capacity as a function of soil organic matter content. Alternatively, this is explained by the difference in the aspect of soils (Lozano-Garcia et al., 2016) northwest and southeast of the tree line running through the central part of the site (Fig. 6A). The map of ECf (Fig. 6C) shows a similar zonation, but with lower values on the wetter northwestern side of the map area. These relationships are consistent with a highly significant negative linear correlation $(r=-0.77 ; p=0.005)$ between ECf and soil moisture content (Fig. 8A), similar to that found in the soil transects (Fig. 3C). The ECx map (Fig. 6D) shows that there is a poor correlation between ECx and ECf. More high-value clusters are present and ECx overall is generally $>130 \mu \mathrm{S} \mathrm{cm}^{-1}$, except for an elliptical, north-south trending patch of ground with a lower ECx in the middle. The results from soil transects, and previous work (Howard and Orlicki, 2015), showed that natural and undisturbed parkland soils had an ECx $\leq 130 \mu \mathrm{S} \mathrm{cm}^{-1}$, whereas demolition site soils were greater. The high-value clusters on the ECx map are attributed to artifact-rich soils, but the low-value cluster in the middle of the map corresponds to an area that soil borings showed was sandier, and contained relatively few artifacts. Hence, ECx data are more consistent with ground truth than ECf. The elevated $\mathrm{pH}$ of anthropogenic soils is usually caused by fragments of mortar and concrete (Howard and Orlicki, 2015). Thus, the $\mathrm{pH}$ map (Fig. 6E) is thought to show the 
distribution of calcareous artifacts and microartifacts, although this could not be verified with soil borings because of the large number of auger refusals.

The map of topsoil temperature (Fig. 7B) is characterized by a series of east-west-trending low-value spots, which correspond to the distribution of trees along the trace of the former alley (Fig. 7A). This suggests that topsoil temperature is controlled primarily by differences in solar insolation, as observed in the soil transects (Fig. 3D). Soil borings showed that penetrability varied as a function of both compaction and artifact content. Hence, the map pattern of penetrability (Fig. 7C) is complex. Aerial photographs from 2005 suggest that the sharp north-southtrending boundary between high-value and low-value clusters in the central part of the map area corresponds to the former location of a dirt road. Hence, the high-value spot of penetrability corresponding to the low-value spot identified by ECx (Fig. 6D) is attributed to compaction by earthmoving equipment. The high-value clusters on the map of MSf (Fig. 7D) are thought to indicate the locations of demolition sites characterized by an abundance of nails (as observed in the field), or coal-related wastes. The map of MSx (Fig. 7E) has fewer high-value spots, probably because gravel-sized artifacts (detectable by field sensor) were removed by sieving in the lab prior to analysis. In contrast to the transect studies (Fig. 3C), there is a poor correlation between penetrability and MSf, whereas there is a highly significant positive linear correlation $(r=0.49 ; p=0.01)$ with MSx. The reason for this is unknown.

\subsection{Geophysical Maps of Detroit City}

The map based on undemolished sites (Fig. 8A) has a low-value spot amidst an overall pattern in which ECx was much higher in the SW than in the other quadrants. This is consistent with mean values (Table 4), and $t$ test calculations indicating that the differences are statistically significant (Table 5). ECx and ECf maps have a similar pattern overall (Figs. 8A and B), but the relationships are better defined by ECx possibly because the ECf dataset was less robust due to equipment failures. The MSx and MSf maps (Fig. 8C and D) have a striking positive magnetic anomaly in the southwest quadrant. The mean values for MSx in the SW and SE quadrants (Table 4) were significantly greater than those for the NW and NE quadrants (Table 5).

In contrast to that of the undemolished sites, the ECx map based on demolition sites has a much more subdued pattern (Fig. 8E). There does not appear to be much difference among sites, although ECx for sites in the NW and NE quadrants were generally lower than to the south. The mean values (Table 4) for the NW and NE quadrants are also lower than those of the other quadrants, and these differences are statistically significant (Table 
5). The ECf map (Fig. 8F) is broadly similar, but differs in having higher values in the NE than in the SE quadrants. The patterns on the MSx and MSf maps (Fig. 8G and H) are also more subdued than for undemolished sites, although the positive magnetic anomaly in the SW quadrant is well defined. Mean MSx values (Table 4) are significantly greater in the southern than the northern quadrants (Table 5).

\section{Discussion}

\subsection{Mapping with Proximal Sensing}

Tall grass interfered with surface scanners such as the MS field probe and the metal detector, although the later seemed useful for detecting subsurface demolition debris in soils under well-mowed grass. Excessive artifacts and compaction restricted use of the EC surface probe, and could potentially damage the instrument. Artifacts interfered with the cone penetrometer, possibly leading to overestimations of compaction and bulk density, but penetrability was well suited for discriminating natural from anthropogenic soils. The utility of soil temperature for soil mapping is uncertain, but $\mathrm{pH}$ differentiated natural from anthropogenic soils, and moisture content appeared useful for proximal sensing of $\wedge$ A horizons. Although the MS2B lab sensor produced a stronger signal, the excellent agreement with lab-based data suggests that MSf is an accurate method for soil mapping by proximal sensing. The lack of agreement between ECf and ECx, and the strong negative correlation between moisture and ECf, contrast with the results of previous studies (e.g., Rhoades et al., 1976; Carroll and Oliver, 2005; Grisso et al., 2009; Doolittle and Brevik, 2014). Soil borings showed that the low-value cluster in the center of the ECx map in Figure 6D corresponded to a patch of sandy soil containing few artifacts. Thus, the ECx geophysical map pattern appears to agree best with an auger-based soil map. This suggests that ECf is being affected in situ, presumably by something of anthropogenic origin. The reason for this discrepancy is uncertain, but ECx is clearly more accurate for detecting differences in soils under the site-specific circumstances studied. Overall, field probes were of greatest utility for site-specific exploration, whereas lab-based measurements were most useful for regional soil mapping..

The results of this study are similar to those from previous work indicating that anthropogenic topsoils in southeastern Michigan have a $\mathrm{pH}>7.0$, an ECx $>130 \mu \mathrm{Sm}^{-1}$, and MSx values of $\chi>150 \times 10^{-8} \mathrm{~m}^{3} \mathrm{~kg}^{-1}$ (Howard and Orlicki, 2015). The corresponding values for natural topsoils are lower. These results are also similar to EC values of 225 to $3620 \mu \mathrm{S} \mathrm{cm}^{-1}$ (Al-Khashman and Shawabkeh, 2009; Karimi et al., 2011; El-Hasan and Lataifeh, 2013), and MS values of 127 to $1959 \times 10^{-8} \mathrm{~m}^{3} \mathrm{~kg}^{-1}$ (Schmidt et al., 2005; Strzyszcz et al., 2006; Hu et al., 2007), or more, reported for urban soils elsewhere. In addition, we found that natural topsoils typically have a penetrability < 
$4000 \mathrm{kPA}$ (< $2000 \mathrm{kPA}$ for sandy soils), whereas values for anthropogenic soils are greater. Thus, penetrability, $\mathrm{pH}$, EC and MS were all found to be excellent indicators of anthropogenic disturbance. As shown by the parkland sites studied (Fig. 4), we found that MS can detect human-altered soils even in the absence of artifacts. Similar results have been reported by forensic scientists (Pringle et al., 2015).

Previous work showed that EC was greatest for calcareous and ferruginous microartifacts in the form of waste building materials (Howard and Orlicki, 2015). Thus, the high-value cluster in the northeastern corner of Detroit (Fig. 8A and B) is thought to reflect the large number of brick-and-mortar homes demolished there. Glass is an insulator, hence the cluster of low values in the center of the large positive ECx anomaly in southwestern Detroit (Fig. 8A) is attributed to fly ash contamination. A comparison of Figure 8C and Figure 2 shows that the positive magnetic anomaly in the SW quadrant was centered roughly on the heavily industrialized west Detroit junction area, and extended across Residential Zone 1 to the Milwaukee junction and Highland Park industrial areas. This anomaly is attributed to magnetic microspheres and other microparticles typical of fly ash (Howard and Orlicki, 2015). Magnetic Fe-oxide microspheres have been widely reported in urban soils impacted industrial activity (Strzyszcz et al., 2006; Gladysheva et al., 2007; El-Baghdadi et al., 2012; El-Hasan and Lataifeh, 2013). They are produced by iron smelting and coal combustion (Lu et al., 2011; Lanteigne et al., 2012). This interpretation is consistent with anecdotal accounts for many decades of the fallout of black metallic dust near Zug Island (Lam, 2010). Fly ash and other coal-related wastes are partly a legacy of the domestic coal-burning era ( 1850-1936) in Detroit. Thus, the fly ash which accounts for the MS and EC anomalies in southwest Detroit (Fig. 8) was probably derived from a complex combination of sources.

Overall, the regional maps generated from lab MS and EC data have a resolution superior to those derived from field-based measurements. The geophysical map patterns show a good overall agreement with the delineations on the anthropogenic surficial geological map (Figs. 2 and 8). The patterns are postulated to reflect the differences between the terrain of HAM-like soils in the NW and NE quadrants (Residential Zone 2), and the terrain of HTMtype soils in Residential Zone 1 to the south. The areas of intense industrial activity in southwest Detroit and along the riverfront are also coincident with the geophysical map patterns. Construction of many homes in Residential Zone 2 pre-dated the advent of diesel-powered earthmoving equipment in 1930s, hence the ground there was relatively undisturbed by construction operations. Thus, anthropogenic soils in Zone 2 are HAM-like in the sense that they show minimal evidence of excavation and backfilling. Nevertheless, the resulting surface mantle of fill is 
actually HTM as currently defined in Soil Taxonomy (Soil Survey Staff, 2014). Natural soils are commonly buried beneath a surface mantle that is typically $<50 \mathrm{~cm}$ thick at undemolished residential sites, but often thicker at demolition sites. In order to be mapped as an anthropogenic soil (e.g., Anthropic Udorthent), there must be a buried soil with a surface mantle $\geq 50 \mathrm{~cm}$ thick (Soil Survey Staff, 2011). If the thickness of HTM surface mantle is less, they are classified as an anthropic phase of a natural soil series. Thus, given the mosaic of undemolished buildings and demolition sites, much of zone 2 will likely be mapped as Native Soil Series-Urban Land complexes by the National Cooperative Soil Survey. Some soils in Detroit impacted by coal combustion products probably will be classified taxonomically as combustic and ashifactic. The MSx map may be useful for delineating the geographic distribution of ashifactic soils.

\subsection{Anthropogenic Map Index}

Increasing anthropogenic impact (i.e. pedoturbation, artifact content, compaction, etc.) tends to limit the suitability of vacant land for repurposing as urban greenspace (Daniels, 2011; USEPA, 2011; Shuster et al., 2014). Hence, it would be useful to have an interpretive urban soil map with delineations based on some measure of soil quality or health, i.e. the sustainable capacity of soil to function as a vital living ecosystem that sustains plants, animals, and humans (Friedman et al., 2001; Scheyer and Hipple, 2005; Zornoza et al., 2015). In this study, penetrability, $\mathrm{pH}, \mathrm{ECx}$ and MSx were all found to be useful for distinguishing between natural and anthropogenic soils. The geophysical map pattern of each parameter was different, but each is thought to increase with increasing level of human disturbance. Hence, an anthropogenic scoring system was formulated which combines these variables into a single overall measure of soil quality (Table 6). The anthropogenic map index (AMI) is defined herein as:

where $A_{p H}, A_{E C}, A_{M S}, A_{p e n}$ are the anthropogenic scores for $p H$, lab electrical conductivity, lab magnetic susceptibility $(\chi)$ and penetrability, respectively. Using equation 1, the ideal natural soil has an AMI of 4.0, and soil health is considered to qualitatively decrease with increasing AMI.

The AMI method was tested using the data from the soil transects. The results (Table 6) show that soils from different land use types have distinctive mean AMI values, and the differences are statistically significant 
(Table 7). In terms of industrial (I), residential demolition (D), undemolished residential (U), and park (P) land use types, AMI values are in the order: $\mathrm{I}>\mathrm{D}>\mathrm{U}>\mathrm{P}$. These relationships are consistent with the concept that AMI is a useful measure of soil quality. The AMI method was used to generate an interpretive map (Fig. 9A) of the same city block-sized parcel of vacant land described above (Figs. 6 and 7). It can be seen that there is a low-value cluster in the north-central part of the map where AMI < 8.0, comparable to the AMI of healthy parkland soil. The low-AMI cluster corresponds to an area with low penetrability where two undemolished homes were situated on relatively undisturbed natural soils (Fig. 6A), and extends southeastward into the patch of sandy soil containing relatively few artifacts noted previously. The remainder of the map is characterized by AMI values comparable to those of demolished and undemolished residential sites in the soil transects (Table 7). The ECx geophysical map pattern (Fig. 9B) is the most similar to that of the AMI map. This is consistent with the interpretation that the ECx approach was more accurate for mapping soils on vacant urban land produced by building demolition.

The interpretive map of Detroit produced using the AMI method (Fig. 9C) delineates areas of low AMI in Residential Zone 2 suggesting that soil health there is comparable to parkland (Fig. 2), whereas higher AMI values extend across Residential Zone 1. The least healthy soils, inferred from very high AMI values, are found in the southwest quadrant corresponding to the magnetic anomaly on the MSx geophysical map (Fig. 9D), centered on the West Detroit Junction-Zug Island zone of heavy industry (Fig. 9E). The MSx anomaly is postulated to delineate the geographic distribution of fly ash contamination, but the possible effects of these fly ash-impacted soils on the environment are not known. The presence of certain artifacts can be beneficial from a geochemical standpoint (Howard and Olszewska, 2011).

\section{Conclusions}

The results of this study suggest that surface scanning in situ with a MS field probe is an accurate method for general use as a proximal sensing tool. However, in practice, better results were obtained after removal of the turf layer, and the method was prone to spurious results from the irregular distribution of magnetic artifacts. The accuracy of the EC field probe tested was questionable. Hence, superior results were obtained ex situ using both EC and MS lab sensors. Lab EC and MS were well suited for regional soil mapping, whereas all of the methods provided at least some useful information for site-specific applications. Tall grass, excessive artifact content, and severe compaction were the greatest limitations of proximal sensing using surface probes. Tall grass interfered with surface scanners, such as the magnetic susceptibility probe and the metal detector, although the later seemed useful 
417 for detecting subsurface debris in demolition site soils. Excessive artifacts and compaction restricted use of the EC

418 surface probe, and could potentially damage the instrument. Artifacts also interfered with the cone penetrometer, but 419 penetrability was useful for discriminating between natural and demolition site soils. Tall grass, above-ground demolition debris and other obstacles are also expected to restrict proximal sensing by mobile units such as groundpenetrating radar and EC mappers. The utility of soil temperature for soil mapping is uncertain, but pH differentiated natural from anthropogenic soils, and moisture content appeared useful for proximal sensing of soil $\wedge$ A horizons. MSx may be especially useful for delineating ashifactic urban soils. Although it is less rapid and more labourintensive than field methods, the lab-based approach still provides a minimally invasive alternative to augering. Lab-based geophysical surveying can be carried out first, and the results used as a guide for an auger-based soil survey. These results support our hypothesis that proximal sensing methods can facilitate soil mapping in urbanized terrain based on the degree of human disturbance, and differences in artifact assemblages related to land use history. which appear to be a useful as a first approximation of a geographical representation of urban soil health. However, additional studies are needed of the effects of artifact weathering on soil health, and of the resilience of urban soils and ecosystems.

Acknowledgments access to their abandoned properties, and to Mike Score for access to Hantz Farms. Thanks to Joe Calus, Eric Gano, Carla Ahlschwede, and Jim Doolittle (NRCS), and to William Shuster (USEPA). Special thanks to EDMAP students Philip Wilt, Steve Brewer, Michael Vandro, and Guilherme Zanon. Funding by the Wayne State University Institute of Environmental Health Sciences, Center for Urban Responses to Environmental Stressors Grant Number P30-ES20957, and U. S. Geological Survey grant G15AC00176, is gratefully acknowledged. The views and conclusions contained in this document are those of the authors and should not be interpreted as necessarily representing the official policies, either expressed or implied, of the U. S. Government.

\section{References Cited}


Al-Khashman, O.A., Shawabkeh, R.A., 2009. Metal distribution in urban soil around steel industry beside Queen Alia Airport, Jordan: Environ. Geochem. Health 31, 717-726.

Bradford, J.M., 1986. Penetrability. In: Klute, A. (ed.), Methods of soil analysis (Part 1). Agronomy 9, Soil Science Society of America, Madison, WI, p. 463-478.

Brevik, E.C., Fenton, T.E., Horton, R., 2004. Effect of daily soil temperature fluctuations on soil electrical conductivity as measured with the Geonics EM-38. Precision Agric. 5, 143-150.

Calkin, P.E., Feenstra, B.H., 1985. Evolution of the Erie-Basin Great Lakes, In: Karrow, P. F., and Calkin, P. E. (Eds.), Quaternary evolution of the Great Lakes. Geological. Association of Canada Special Paper 30, 149-170.

Carroll, Z.L., Oliver, M.A., 2005. Exploring the spatial relations between soil physical properties and apparent electrical conductivity 128, 354-374.

Daniels, W.L., 2011. Managing urban soils. In: Goatley, M., and Hensler, K.. (Eds.), Urban nutrient management handbook. Virginia Cooperative Extension, College of Agriculture and Life Sciences, Virginia Polytechnic Institute and State University, Blacksburg, VA, 200 pp.

Davidson, G.W., 1953. Industrial Detroit after World War I: 1919-1921. M. A. thesis, Dept. of History, Wayne State University, Detroit, MI, 176 pp.

Davis, J.C., 1986. Statistics and data analysis in geology. Wiley, New York, 646 pp.

Doolittle, J.A., Brevik, E.C., 2014. The use of electromagnetic induction techniques in soils studies. Geoderma 223225, 33-45.

Doxiadis, C.A., 1967. Emergence and growth of an urban region: The developing urban Detroit area. Detroit Edison Company Pub., 408 pp. 
El Baghdadi, M., Barakat, A., Sajieddine, M., Nadem, S., 2012. Heavy metal pollution and soil magnetic susceptibility in urban soil of Beni Mellal City (Morocco): Environ. Earth Sci. 66, 141-155.

477

478

479

480

481

482

483

484

485

486

487

488

489

490

491

492

493

494

495

496

497

498

499
El-Baghdadi, M.,Barakat, A., Sajieddine, M., Nadem. S.,2012. Heavy metal pollution and soil magnetic susceptibility in urban soil of Beni Mellal City (Morocco). Environ. Earth Sci. 66, 141-155.

El Hasan, T., Lataifeh, M., 2013. Field and dual magnetic susceptibility proxies for heavy metal pollution assessment in the urban soil of Al-Karak City, South Jordan: Environ. Earth Sci. 69, 2299-2310.

Fairbanks, R.G., Mortlock, R.A., Chiu, T. C., Cao, L, Kaplan, A., Guilderson, T.P., Fairbanks, T.W., Bloom, A.L., 2005. Marine Radiocarbon Calibration Curve Spanning 0 to 50,000 Years B.P. Based on Paired ${ }^{230} \mathrm{Th} /{ }^{234} \mathrm{U} /{ }^{238} \mathrm{U}$ and ${ }^{14} \mathrm{C}$ Dates on Pristine Corals. Quat. Sci. Rev. 24, 1781-1796.

Farmer, S., 1890. History of Detroit and Wayne County and early Michigan. Silas Farmer \& Co. Pub., Detroit, Michigan, 1028 pp.

Friedman, D., Hubbs, M., Tugel, A., Seybold, C., Sucik, M., 2001. Guidelines for soil quality assessment in conservation planning. USDA-NRCS Soil Quality Institute, 38 pp.

Gladysheva, M. A., Ivanov, A.V., Stroganova, M.N., 2007. Detection of technogenically contaminated soil areas based on their magnetic susceptibility. Eurasian Jour. Soil Sci. 40, 215-222.

Grisso, R., Alley, M., Holshouser, D., Thomason, W., 2009. Precision farming tools: Soil electrical conductivity. Virginia Cooperative Extension Pub. 442-508. Virginia Polytechnic Institute and State University, 6 pp. 
Herdendorf, C.E., Bailey, M.L. 1989. Evidence for an early delta of the Detroit River in western Lake Erie. Ohio Journal of Science 89: 16-22.

Howard, J.L. 2010, Late Pleistocene glaciolacustrine sedimentation and paleogeography of southeastern Michigan, USA. Sedim. Geol. 223, 126-142.

Howard, J.L., Olszewska. D., 2011. Pedogenesis, geochemical forms of heavy metals, and artifact weathering in an urban soil chronosequence, Detroit, Michigan. Envir. Poll. 159, 754-761.

Howard, J.L., Putnam, S., Moorhead, S., Schooch, R., 2013a (unpub.), Preliminary Quaternary geologic map of the Detroit, Michigan quadrangle. Scale: 1:24,000.

Howard, J.L., Dubay, B.R., Daniels, W. L., 2013b. Artifact weathering, anthropogenic microparticles, and lead contamination in urban soils at former demolition sites, Detroit, Michigan. Envir. Poll. 179: 1-12.

Howard, J.L., 2014. A proposal to add anthrostratigraphic and technostratigraphic units to the stratigraphic code for classification of anthropogenic Holocene deposits. The Holocene 24, 1856-1861.

Howard, J.L., Shuster, W.B., 2015. Experimental order 1 soil survey of vacant urban land, Detroit, Michigan. Catena 126, 220-230.

Howard, J.L., Ryzewski, K., Dubay, B.R, Killion, T.K., 2015. Artifact preservation and post-depositional siteformation processes in an urban setting: A geoarchaeological study of a 19th century neighborhood in Detroit, Michigan. Jour. Archaeol. Sci. 53, 178-189.

Howard, J.L., 2015. Glaciolacustrine history of the Huron-Erie lowland in the southeastern Great Lakes region (USA) revisited. Jour. Great Lakes Res. 41, 0-00. 
528

529

530

531

532

533

534

535

536

537

538

539

540

541

542

543

544

545

546

547

548

549

550

551

552

553

554

Howard, J.L., Orlicki, K. M., 2015. Effects of anthropogenic particles on the chemical and geophysical properties of urban soils, Detroit, Michigan. Soil Science 180, 154-166.

Howard, J.L., Orlicki, K. M., 2016. Composition, micromorphology and distribution of microartifacts in anthropogenic soils, Detroit, Michigan USA. Catena 138, 38-51.

Hu, X. F., Su, Y., Ye, R., Li, X. Q., Zhang, G.L., 2007. Magnetic properties of the urban soils in Shanghai and their environmental implications: Catena 70, 428-436.

Hyde, C. K., 1980. Detroit: An industry history guide. Detroit Historical Society, Detroit, MI.

Hyde, C. K., 2001. Detroit the dynamic: The industrial history of Detroit from cigars and cars. Michigan Historical Review 27, 57-73.

IUSS Working Group, 2006. World Reference Base for Soil Resources 2006: World Soil Resources Report 103, Food and Agriculture Organization United Nations, Rome, Italy, 145 p.

Kapper, K.L., Anesin, D., Donadini, F., Angelucci, D.E., Cavulli, F., Pedrotti, A., Hirt, A.M., 2014. Linking site formation processes to magnetic properties. Rock and archaeomagnetic analysis of the combustion levels at Riparo Gaban (Italy). Jour. Archaeol. Sci. 41, 836-855.

Karimi, R., Ayoubi, S., Jalalian, A., Sheikh-Hosseini, A.R., Afyuni. M., 2011. Relationships between magnetic susceptibility and heavy metals in urban topsoils in the arid region of Isfahan, central Iran. Jour. Appl. Geophy. 74, 1-7.

Kincare, K., Larson, G.J., 2009. Evolution of the Great Lakes. In: Schaetzl, R., Darden, J., Brandt, D. (Eds.) Michigan geography and geology. Pearson, New York, p. 174-190. 
556 557 558

Lam, T., 2010. 48217: Life in Michigan’s most polluted zip code - Illness is just as pervasive as metallic dust cover. The Detroit Free Press, June 20, 2010.

Lanteigne, S., Schindler, M., McDonald, A.M., Skeries, K., Abdu, Y., Mantha, N.M., Murayama, M., Hawthrone, F.C., Hochella, M.F., Jr., 2012. Mineralogy and weathering of smelter-derived spherical particles in soils: Implications for the mobility of Ni and $\mathrm{Cu}$ in the surficial environment. Water Air Soil Pollut. 223, 3619-3641.

Larson, J. D., 1977. Soil survey of Wayne County area, Michigan. U.S. Gov. Printing Office, 83 pp.

Leverett, F.B., Taylor, F.B., 1915. The Pleistocene of Indiana and Michigan and the history of the Great Lakes. U. S. Geological Survey Monograph 53, 529 pp.

Lozano-Garcia, B., Parras-Alcantara, L., Brevik, E.C., 2016. Impact of topographic aspect and vegetation (native and forested areas) on soil organic carbon and nitrogen budgets in Mediterranean natural areas. Sci. Total Envir. 544, 963-970.

Lu, S.G., Wang, H.Y., Guo, J.L., 2011. Magnetic enhancement of urban roadside soils as a proxy of degree of pollution by traffic-related activities. Environ. Earth Sci. 64, 359-371.

MacDonald, C., 2007. City Airport becomes wasteland. The Detroit News, Dec. 10, 2007.

Magiera, T., Parzentny, H., Rog, L., Chybiorz, R., Wawer, M., 2015. Spatial variation of soil magnetic susceptibility in relation to different emission sources in southern Poland. Geoderma 255-256, 94-103.

Miller, R.E., Hazard, J., Howes, S., 2001. Precision, accuracy, and efficiency of four tools for measuring soil bulk density or strength. U. S. D. A. Forest Service Gen. Tech. Rpt. PNW-RP-532, 17 pp. 
583 584 585

586 587 588 589 590 591 592 593 594 595 596 597 598 599 600 601 602 603 604 605 606 607 608 609 610

Pringle, J.K., Giubertoni, M., Cassidy, N.J., Wisniewski, K.D., Hansen, J.D., Linford, N.T., Daniels, R.M., 2015. The use of magnetic susceptibility as a forensic search tool. Forensic Sci. Intern. 246, 31-42.

Raphael, C.N., Jaworski, E. (1982) The St. Clair River delta, a unique lake delta. Geographical Bull. 21, 7-28.

Rhoades, J.D., Raats, P.A.C., Prather, R.J., 1976. Effects of liquid-phase electrical conductivity, water content, a nd surface conductivity on bulk electrical conductivity. Soil Sci. Soc. Am. J. 40, 651-655.

Roock, W. E., 1964. Automobile age in the making: Industrial Detroit 1880-1900. M. A. thesis, Dept. of History, Wayne State University, 100 pp.

Rosen, A.R., 1991. Guide to artifacts: Microartifacts and the study of ancient societies: Biblical Archaeol. 54, 97103.

Santini, T.L., Fey, M.V., Smirk, M.N., 2013. Evaluation of soil analytical methods for the characterization of alkaline Technosols: I. Moisture content, pH, and electrical conductivity. Jour. Soils Seds. 13:1141oils .

Scheyer, J.M., Hipple, K.W., 2005. Urban soil primer. USDA-NRCS, National Soil Survey Center, Lincoln, NE, 74 pp.

Schmidt, A., Yarnold, R., Hill, M., Ashmore, M., 2005. Magnetic susceptibility as proxy for heavy metal pollution: a site study. Jour. Geochem. Explor. 85, 109-117.

Schoeneberger, P.J., Wysocki, D.A., Benham, E.C., Soil Survey Staff, 2012. Field book for describing and sampling soils, Version 3.0. National Resources Conservation Service, National Soil Survey Center, Lincoln, NE.

Sherwood, S.C., 2001. Microartifacts. In: Goldberg, P., Holliday, V. T. and Ferring, C. R., Earth sciences in archaeology, Kluwer Academic, New York, pp. 327-351. 
614 Shuster, W. D., Dadio, S., Drohan, P., Losco, R., Shaffer, J., 2014. Residential demolition and its impact on vacant 615 lot hydrology: Implications for the management of storm water and sewer system overflows. Landscape and Urban 616 Planning 125, 48-56.

617

618 Sinclair, R., 1972. The face of Detroit: A spatial synthesis. U. S. Office of Education, Dept. of Health, Education 619 and Welfare OEG-0-70-2030, 72 pp.

620

Soil Survey Staff, 2011. Buried soils and their effect on taxonomic classification. Soil Survey Technical Note no. 10, USDA-NRCS, Lincoln, NE, 7 pp.

623 DC. anomalies in trace metal and iron contents: a case study in the Katowice Forest district: Polish Jour. Environ. Studies 15, 176-184.

630

USEPA, 2011. Evaluation of urban soils: Suitability for green infrastructure or urban agriculture. EPA Pub. no. 905R1103, 20 pp.

634 Vodyanitskii, Y.N., Shoba, S.A., 2015. Magnetic susceptibility as an indicator of heavy metal contamination of 635 urban soils (Review): Moscow Univ. Soil Sci. Bull. 70, 10-16. measurements of urban forest topsoils using the MS2D sensor: Environ. Earth Sci. 61, 223-230. 
640 Zornoza, R., Acosta, J.A., Bastida, F., Dominguez, S.G., Toledo, D.M., Faz, A., 2015. Identification of sensitive 641 indicators to assess the interrelationship between soil quality, management practices and human health. Soil 1, 173642185.

643

Figure 1. Airborne LiDAR imagery of Detroit, Michigan (USA) area showing annotated glacial geomorphical features and locations of the three soil transects (T1-3) studied. Modified after Sherzer (1916). D, Detroit city hall; hillshade with $5 \mathrm{X}$ vertical exaggeration.

656 detailed survey area (LSM), and sample locations (black squares) used to make geophysical maps. Note that map delineations are subject to change as land use varies over time, e.g., remediated industrial land converted to parkland. D, Detroit city hall; W, Windsor, Ontario, Canada. Industrial centers: DJ, West Detroit Junction; ZU, Zug

662 Island; MJ, Milwaukee Junction; HP, Highland Park; CC, Conner Creek. See Table 1 for further explanation. 
666

667

668

669

670

671

672

673

674

675

676

677

678

679

680

681

682

683

684

685

686

687

688

689

690

691

692

693

Figure 4. Soil geophysical properties as a function of differences in land use type in selected transects: A, Field magnetic susce;ptibility; transect 2; B, Field magnetic susceptibility; transect 1; C, Field electrical conductivity transect 1; D, Penetrability; transect 1. Land use types: P, Parkland; H, undemolished residential; D, residential demolition; I, industrial. See Figs. 1 and 2 for transect locations.

Figure 5. Detailed study of vacant urban land created by building demolition in Detroit, Michigan: A, Area mapped in this study, and previous study on Wisner St. (Howard and Shuster, 2015). Note: Area as it appeared in 1981 (left) and 2010 (right); B, Sampling plan (10 m x 15 m grid) used in this study to map area. See Fig. 2 for site location.

Figure 6. Characteristics of detailed survey area: A, Features of the site as it appeared in 2015; B, Soil moisture (MOs); C, field electrical conductivity (ECf); D, lab electrical conductivity (ECx); E, pH (triangles indicate sample locations). See Supplementary Data Figure 1 for further explanation.

Figure 7. Characteristics of detailed survey area: A, Timing of demolition operations; B, Soil temperature (TMp); C, penetrability (PEn); D, field magnetic susceptibility (MSf); E, lab magnetic susceptibility (MSx). Triangles indicate sample locations. See Supplementary Data Figure 1 for further explanation.

Figure 8. Geophysical characteristics of urban soils in Detroit, Michigan. Undemolished residential sites: A, lab EC; B, field EC; C, lab MS; D, field MS. Residential demolition sites: E, lab EC; F, field EC; G, lab MS; H, field MS. See Fig. 2 and Supplementary Data Figure 2 for further explanation. Maps at same scale. Trace of Detroit River shown for reference.

Figure 9. Comparisons with interpretive maps based on the anthropogenic map index (AMI). Detailed map area: A, Lab-based EC; B, corresponding AMI map. Regional map area: C, lab-based MS; D, Corresponding AMI map; E, AMI map of Detroit city (see Figs. 2 and 8). Note that an AMI $<8.0$ is thought to reflect a level of soil quality comparable to that of parkland (see text and Table 7 for details). 

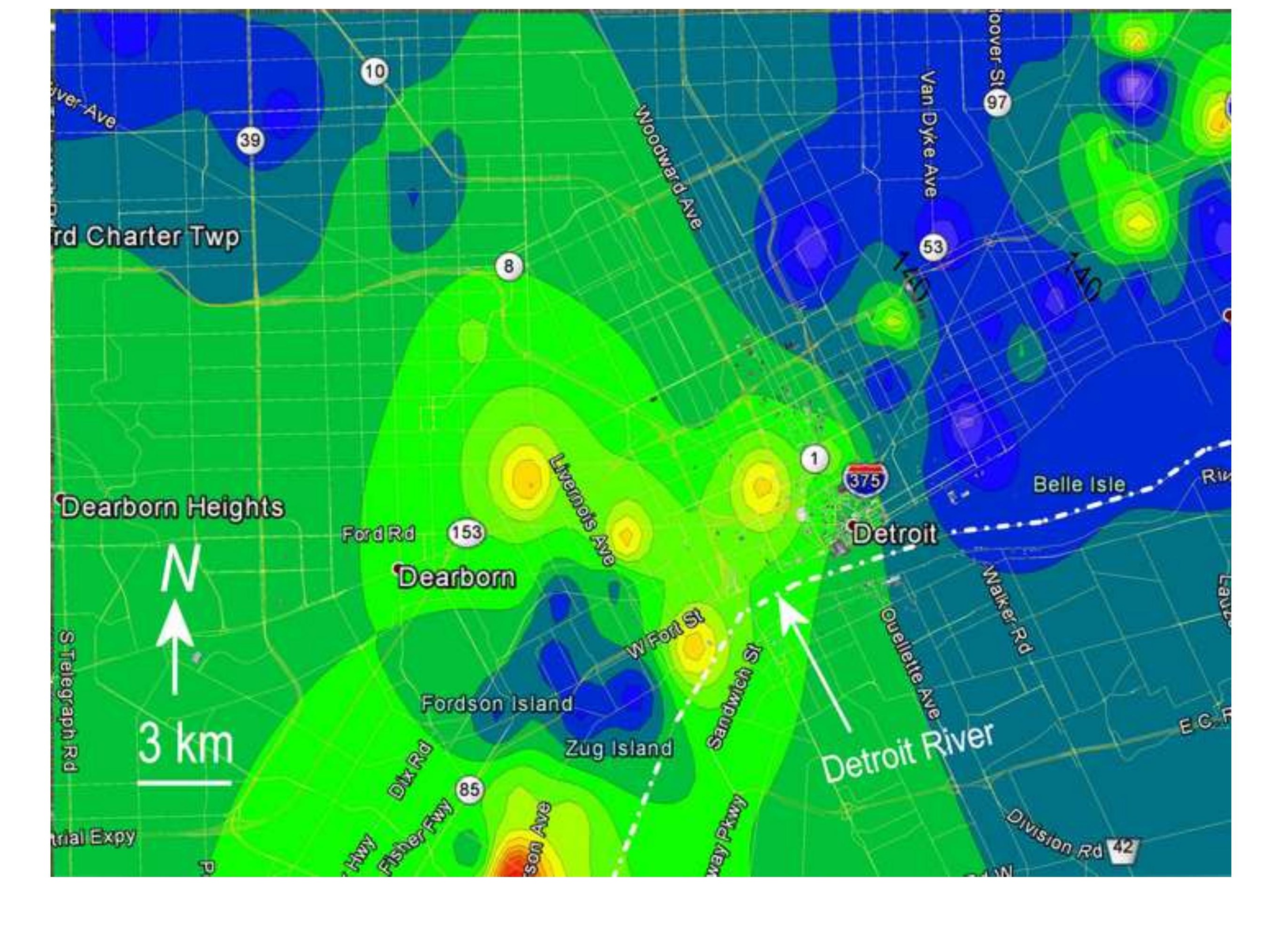
Table 1. Characteristics of anthropogenic surficial geological map units, Detroit, Michigan, USA (see Fig. 2).

\begin{tabular}{|c|c|c|c|c|c|c|c|}
\hline \multicolumn{3}{|c|}{ Anthropogenic Surficial Geologic Unit } & \multirow{2}{*}{$\begin{array}{l}\text { Type of } \\
\text { Site }^{a}\end{array}$} & \multirow[b]{2}{*}{ Soil Type } & \multirow[t]{2}{*}{ Description } & \multicolumn{2}{|c|}{ Artifacts $^{\mathrm{b}}$} \\
\hline $\begin{array}{c}\text { Map } \\
\text { Symbol }\end{array}$ & $\begin{array}{l}\text { Urban Land } \\
\text { Use Type }\end{array}$ & Zone & & & & Abundance & Type \\
\hline QaP & Park & & A & Native Series & $\begin{array}{l}\text { Rare artifacts and evidence of } \\
\text { human disturbance; Native soil } \\
\text { parent materials }\end{array}$ & None & -- \\
\hline QaR2 & \multirow[t]{2}{*}{ Residential } & Zone 2 & $A, B, D$ & \multirow{4}{*}{$\begin{array}{l}\text { Anthropic and } \\
\text { Anthroportic } \\
\text { Udorthents }\end{array}$} & $\begin{array}{l}\text { Monocyclic demolition sites } \\
\text { predominate; Artifacts from } 20^{\text {th }} \\
\text { century common; Complex native } \\
\text { and human-transported soil parent } \\
\text { materials }\end{array}$ & $\begin{array}{l}\text { Few to very } \\
\text { abundant }\end{array}$ & $\begin{array}{l}b, m, t \\
d, c, w \\
h, g, n\end{array}$ \\
\hline QaR1 & & Zone 1 & $\mathrm{~B}, \mathrm{C}, \mathrm{D}$ & & $\begin{array}{l}\text { Polycyclic demolition sites } \\
\text { predominate; Artifacts from the } \\
19^{\text {th }} \text { century common; Human- } \\
\text { transported soil parent material } \\
\text { dominant }\end{array}$ & $\begin{array}{l}\text { Moderately } \\
\text { to very } \\
\text { abundant }\end{array}$ & $\begin{array}{l}\mathrm{b}, \mathrm{m}, \mathrm{t} \\
\mathrm{d}, \mathrm{c}, \mathrm{w} \\
\mathrm{h}, \mathrm{g}, \mathrm{n}\end{array}$ \\
\hline QaM & Manufactured & & C, D & & $\begin{array}{l}\text { Land covered and sealed by } \\
\text { concrete, asphaltic pavement, etc. }\end{array}$ & None & -- \\
\hline QaI & Industrial & & C, D & & $\begin{array}{l}\text { Manufacturing and power- } \\
\text { generation industries, airports, } \\
\text { marinas, railroads and dredgings; } \\
\text { Coal-related and iron smelting } \\
\text { wastes common; Human- } \\
\text { transported soil parent material } \\
\text { dominant }\end{array}$ & $\begin{array}{l}\text { Moderately } \\
\text { to very } \\
\text { abundant }\end{array}$ & $\begin{array}{l}c, k, d, s, \\
b, m\end{array}$ \\
\hline $\mathrm{QaC}$ & Cemetery & & $A, B$ & $\begin{array}{l}\text { Anthraltic } \\
\text { Udorthents }\end{array}$ & $\begin{array}{l}\text { Burial plots, crypts and } \\
\text { mausoleum; Complex human- } \\
\text { altered and human-transported } \\
\text { soil parent materials }\end{array}$ & None & -- \\
\hline
\end{tabular}

a Site Types: A, Native undisturbed; B, Undemolished building on weakly disturbed native; C, Undemolished building on fill showing strong human disturbance; $D$, Demolition site with fill showing strong human disturbance: polycyclic sites showed evidence for multiple demolition events; monocylic or first-cycle sites have undergone one demolitionrelated backfilling event.

${ }^{\mathrm{b}}$ Artifacts: b, brick; m, mortar; t, concrete; d, coal cinders; c, coal; coked coal; w, wood; h, charcoal; g, glass; n, nails; s, iron smelting slag. 
Table 2. Variations in geophysical parameters for combined transects as a function of differences in land use type.

\begin{tabular}{|l|c|c|c|c|c|c|c|c|c|}
\hline & \multicolumn{9}{|c|}{ Geophysical Parameter } \\
\hline Land Use Type & \multicolumn{2}{|c|}{$\begin{array}{c}\text { Lab Electrical } \\
\text { Conductivity } \\
\left(\mu \mathrm{S} \mathrm{cm}^{-1}\right)\end{array}$} & \multicolumn{2}{|c|}{$\begin{array}{c}\text { Penetrability } \\
\left(\times 10^{2} \mathrm{kPA}\right)\end{array}$} & $\begin{array}{c}\text { Field magnetic } \\
\text { Susceptibility } \\
\left(10^{-5} \mathrm{SI}\right)\end{array}$ & $\begin{array}{c}\text { Lab Magnetic } \\
\text { Susceptibility } \\
\left(10^{-8} \mathrm{~m}^{3} \mathrm{~kg}^{-1}\right)\end{array}$ & $\begin{array}{c}\text { Sample } \\
\text { Size }\end{array}$ \\
\hline & $\mathrm{Xa}{ }^{*}$ & $\mathrm{Sa}$ & $\mathrm{Xa}$ & $\mathrm{Sa}$ & $\mathrm{Xg}$ & $\mathrm{Sg}$ & $\mathrm{Xg}$ & $\mathrm{Sg}$ & $\mathrm{n}$ \\
\hline Parkland & 135.0 & 21.1 & 34.4 & 10.9 & 26.9 & 1.8 & 37.6 & 2.1 & 7 \\
\hline Industrial/Railroad & 245.8 & 90.1 & 59.1 & 20.7 & 188.2 & 2.1 & 479.6 & 2.8 & 11 \\
\hline $\begin{array}{l}\text { Residential } \\
\text { demolition }\end{array}$ & 241.4 & 199.6 & 61.0 & 15.5 & 71.7 & 2.2 & 73.4 & 2.2 & 36 \\
\hline $\begin{array}{l}\text { Undemolished } \\
\text { residential }\end{array}$ & 204.9 & 55.8 & 37.2 & 12.2 & 23.9 & 3.1 & 74.0 & 3.1 & 18 \\
\hline
\end{tabular}

*Xa, arithmetic mean; Sa, arithmetic standard deviation; $\mathrm{Xg}$, geometric mean; Sg, geometric standard deviation. 
Table 3. Calculated $t$-values for testing differences in means for combined transects, and their statistical significance.

\begin{tabular}{|c|c|c|c|c|c|c|c|c|c|c|c|c|c|c|c|c|}
\hline & \multicolumn{4}{|c|}{ Electrical Conductivity } & \multicolumn{4}{|c|}{ Penetrability } & \multicolumn{4}{|c|}{ Field Magnetic Susceptibility } & \multicolumn{4}{|c|}{ Lab Magnetic Susceptibility } \\
\hline & Park & Ind & Demo & Undem & Park & Ind & Demo & Undem & Park & Ind & Demo & Undem & Park & Ind & Demo & Undem \\
\hline Parkland & -- & $3.17 * * *$ & 1.39 & $3.19 * * *$ & -- & $2.89 * *$ & $4.32 * * *$ & 0.53 & -- & $5.86 * * *$ & $3.13 * * *$ & 0.26 & -- & $6.33^{* * *}$ & $2.13^{* *}$ & 1.46 \\
\hline Industrial & -- & -- & 0.07 & 1.52 & -- & -- & 0.33 & $3.60 * * *$ & -- & -- & 0.60 & $5.37 * * *$ & -- & -- & $6.52 * * *$ & $4.49 * * *$ \\
\hline Demolition & -- & -- & -- & 0.76 & -- & -- & -- & $5.68 * * *$ & -- & -- & -- & $4.16 * * *$ & -- & -- & -- & 0.03 \\
\hline Undem. & -- & -- & -- & -- & -- & -- & -- & -- & -- & -- & -- & -- & -- & -- & -- & -- \\
\hline & & & & & & & & & & & & & & & & \\
\hline & & & & & & & & & & & & & & & & \\
\hline
\end{tabular}

*Probably significant, $p=0.10 ; * *$ Significant, $p=0.05 ; * * *$ Highly significant, $p=0.01$ 
Table 4. Arithmetic mean (Xa) and geometric mean (Xg) values of lab magnetic susceptibility (MS) and electrical conductivity (EC) for Detroit soils in different informally defined map quadrants, as a function of land use type.

\begin{tabular}{|c|c|c|c|c|c|c|c|c|c|c|c|c|}
\hline \multirow{3}{*}{ Quadrant } & \multicolumn{6}{|c|}{ Undemolished sites } & \multicolumn{6}{|c|}{ Demolition site } \\
\hline & \multicolumn{3}{|c|}{$\operatorname{MS}\left(10^{-8} \mathrm{~m}^{3} \mathrm{~kg}^{-1}\right)$} & \multicolumn{3}{|c|}{$\mathrm{EC}\left(\mu \mathrm{S} \mathrm{cm}^{-1}\right)$} & \multicolumn{3}{|c|}{$\operatorname{MS}\left(10^{-8} \mathrm{~m}^{3} \mathrm{~kg}^{-1}\right)$} & \multicolumn{3}{|c|}{$\mathrm{EC}\left(\mu \mathrm{Scm}^{-1}\right)$} \\
\hline & $\mathrm{Xg}$ & $\mathrm{Sg}$ & $\mathrm{n}$ & $\mathrm{Xa}$ & $\mathrm{Sa}$ & $\mathrm{n}$ & $X g$ & $\mathrm{Sg}$ & $n$ & $\mathrm{Xa}$ & Sa & $\mathrm{n}$ \\
\hline Northwest & 18.9 & 1.3 & 5 & 153.0 & 30.8 & 10 & 48.4 & 2.4 & 22 & 214.2 & 99.3 & 28 \\
\hline Southwest & 195.0 & 1.8 & 15 & 207.1 & 80.1 & 15 & 136.8 & 1.7 & 18 & 304.9 & 258.2 & 18 \\
\hline Northeast & 52.1 & 1.6 & 21 & 146.9 & 79.1 & 27 & 44.1 & 1.9 & 7 & 136.0 & 44.1 & 8 \\
\hline Southeast & 133.4 & 1.6 & 12 & 136.6 & 55.3 & 12 & 93.6 & 2.1 & 15 & 189.2 & 57.4 & 15 \\
\hline
\end{tabular}


Table 5. Calculated $t$-values for testing differences between means for lab-based measurements from different Detroit map quadrants, and their statistical significance.

\begin{tabular}{|c|c|c|c|c|c|c|c|c|c|c|c|c|c|c|c|c|}
\hline \multirow{3}{*}{ Quadrant } & \multicolumn{8}{|c|}{ Magnetic Susceptibility } & \multicolumn{8}{|c|}{ Electrical Conductivity } \\
\hline & \multicolumn{4}{|c|}{ Undemolished } & \multicolumn{4}{|c|}{ Demolition } & \multicolumn{4}{|c|}{ Undemolished } & \multicolumn{4}{|c|}{ Demolition } \\
\hline & NW & SW & $\mathrm{NE}$ & SE & NW & SW & $\mathrm{NE}$ & SE & NW & SW & $\mathrm{NE}$ & SE & NW & SW & $\mathrm{NE}$ & SE \\
\hline Northwest & -- & $8.67^{* * * *}$ & $4.32 * * * *$ & $8.91 * * * *$ & -- & $4.76 * * * *$ & 0.26 & $2.46^{* *}$ & -- & $2.03 *$ & 0.24 & 0.83 & -- & $3.50 * * * *$ & $2.15^{* *}$ & 0.90 \\
\hline Southwest & -- & -- & $7.25 * * * *$ & $1.86 *$ & -- & -- & $4.72 * * * *$ & $1.79 *$ & -- & -- & $2.35^{* *}$ & $2.59 * *$ & -- & -- & $7.28 * * * *$ & $5.73 * * * *$ \\
\hline Northeast & -- & -- & -- & $4.28 * * * *$ & -- & -- & -- & $2.37 * *$ & -- & -- & -- & 0.41 & -- & -- & -- & $2.28^{* *}$ \\
\hline
\end{tabular}

*Probably significant, $p=0.10 ;{ }^{* *}$ Significant, $p=0.05 ;{ }^{* *}$ Highly significant, $p=0.01 ; * * * *$ Very highly significant, $p=0.005$ 
Table 6. Scoring system used to rate urban soils for anthropogenic map index. EC $\left(\mu \mathrm{S} \mathrm{cm}^{-1}\right)$; MS $\left.10^{-8} \mathrm{~m}^{3} \mathrm{~kg}^{-1}\right)$; Penetrability (x $\left.10^{2} \mathrm{kPA}\right)$.

\begin{tabular}{|c|c|c|c|c|c|c|c|}
\hline $\mathrm{pH}$ & Score & $\mathrm{ECX}$ & Score & MSx & Score & Pen & Score \\
\hline$\leq 7.0$ & 1.0 & $0-140$ & 1.0 & $0-50$ & 1.0 & $0-20$ & 1.0 \\
\hline$>7.0$ & 2.0 & $141-210$ & 2.0 & $51-100$ & 2.0 & $21-40$ & 2.0 \\
\hline & & $211-280$ & 3.0 & $101-150$ & 3.0 & $41-60$ & 3.0 \\
\hline & & $281-350$ & 4.0 & $151-200$ & 4.0 & $61-80$ & 4.0 \\
\hline & & $>350$ & 5.0 & $201-250$ & 5.0 & & \\
\hline & & & & $251-300$ & 6.0 & & \\
\hline & & & $>300$ & 7.0 & & \\
\hline
\end{tabular}


Table 7. Calculated $t$-values testing statistical significance of differences in mean anthropogenic map index (AMI) values.

\begin{tabular}{|l|l|l|l|l|}
\hline & Parkland & Demolition site & Industrial site & Undemolished res. \\
\hline Parkland & -- & $4.10^{* * * *}$ & $8.07 * * * *$ & $2.38^{* *}$ \\
\hline Demolition site & -- & -- & $2.78^{* *}$ & $1.78^{*}$ \\
\hline Industrial site & -- & -- & -- & $4.71^{* * * *}$ \\
\hline Undemolished res. & -- & -- & -- & -- \\
\hline Mean (AMI) & 7.0 & 11.0 & 14.0 & 9.2 \\
\hline Range (AMI) & $4.0-10.0$ & $7.0-16.0$ & $10.0-18.0$ & $5.0-14.0$ \\
\hline n & 11 & 14 & 11 & 18 \\
\hline
\end{tabular}

*Probably significant, $p=0.10 ; * *$ Significant, $p=0.05 ; * * *$ Highly significant, $p=0.01 ; * * * *$ Very highly significant, $p=0.005$. 


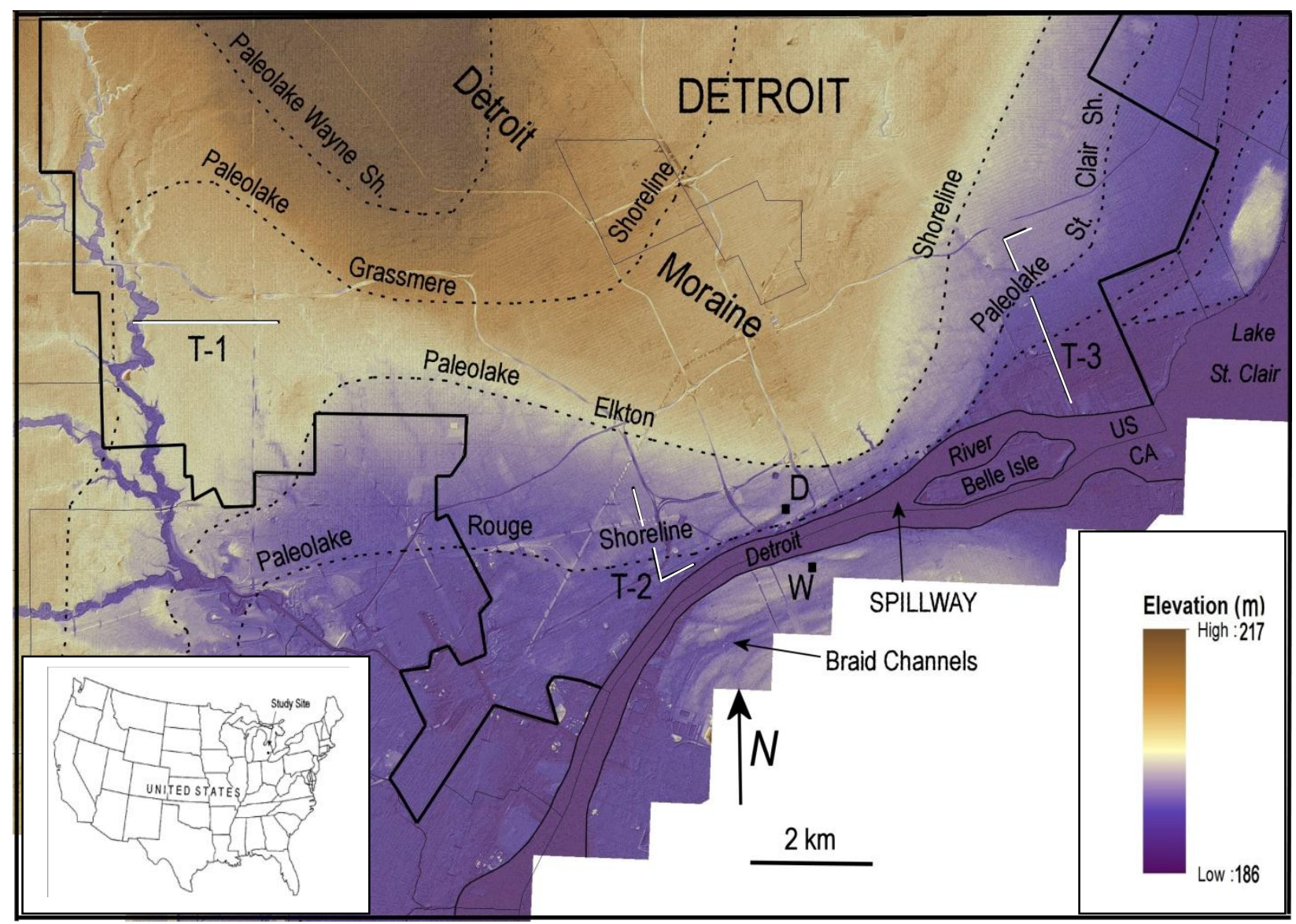




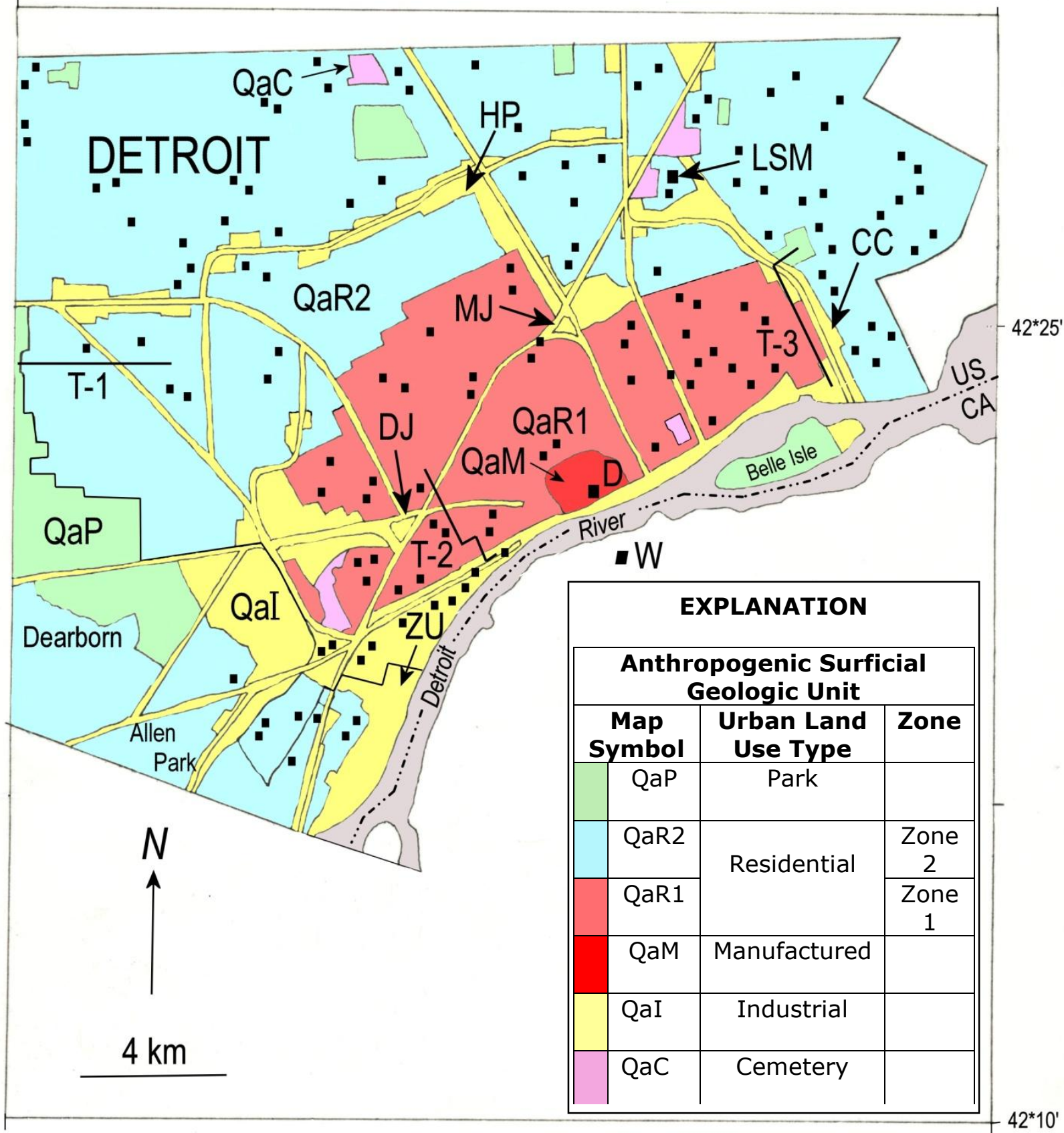


Figure 3
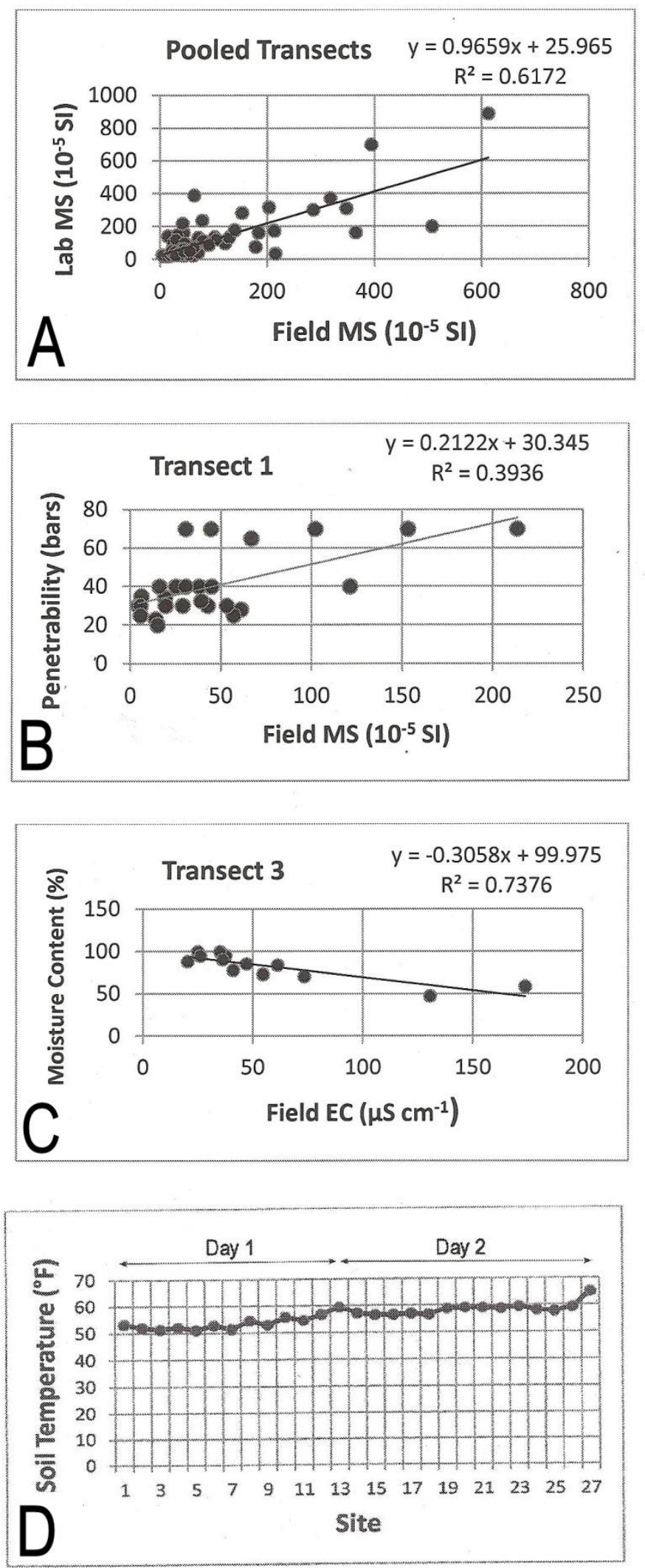
Figure 4
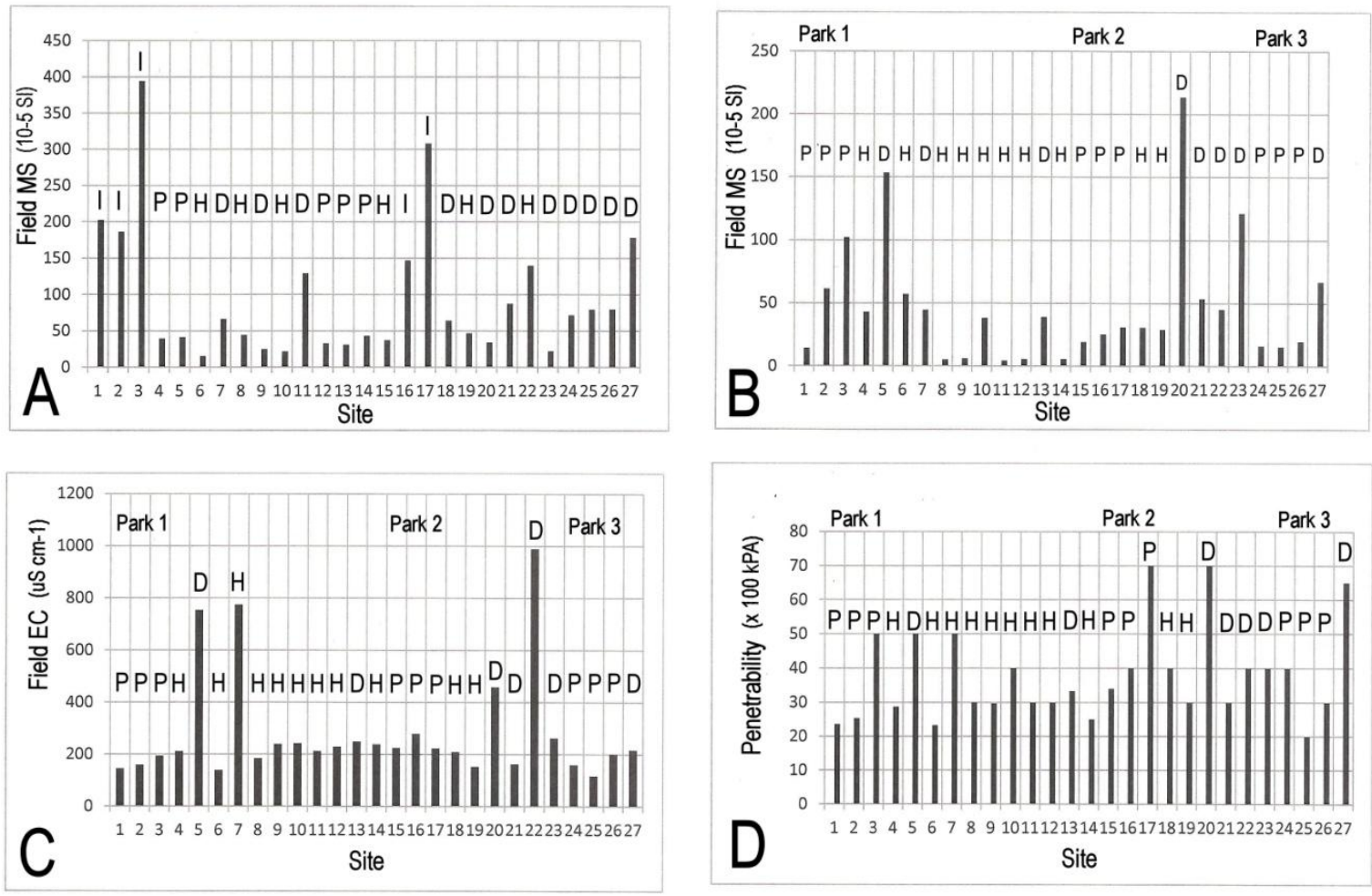


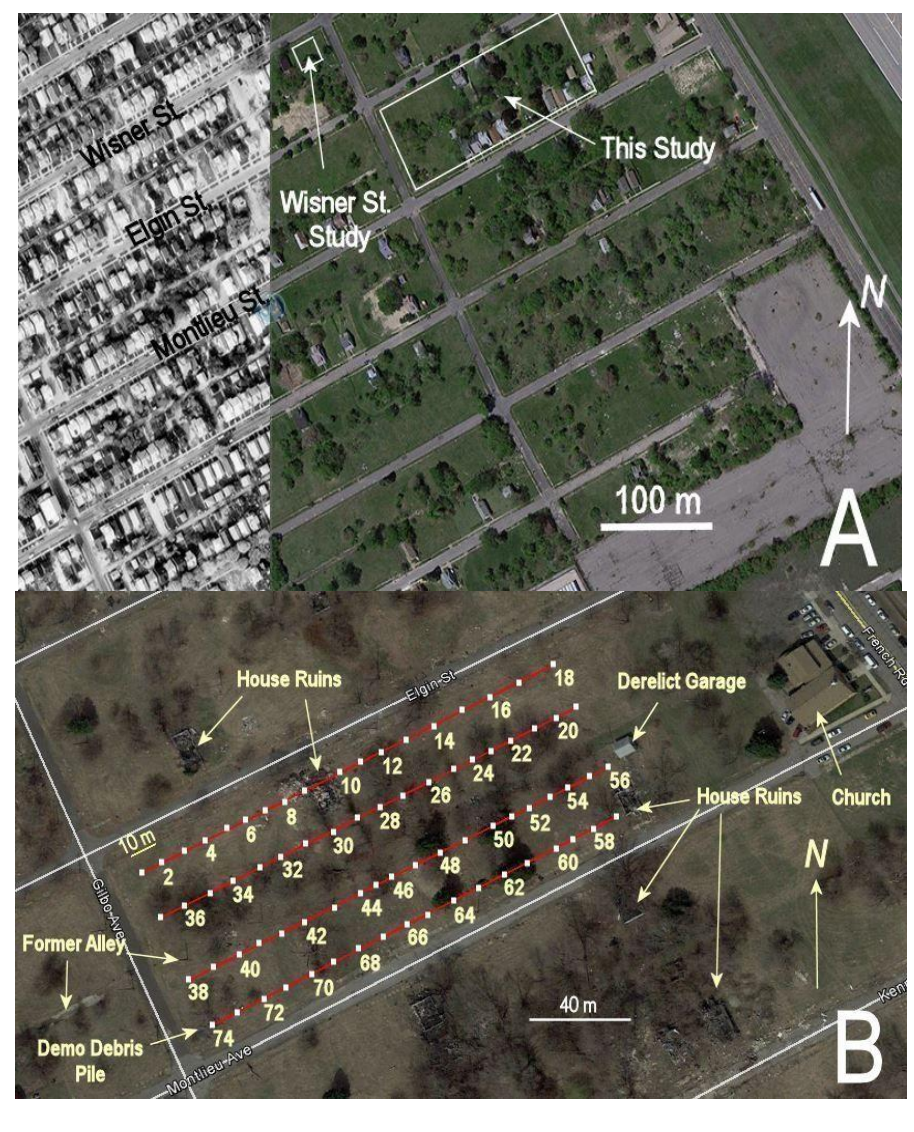

Figure 5 


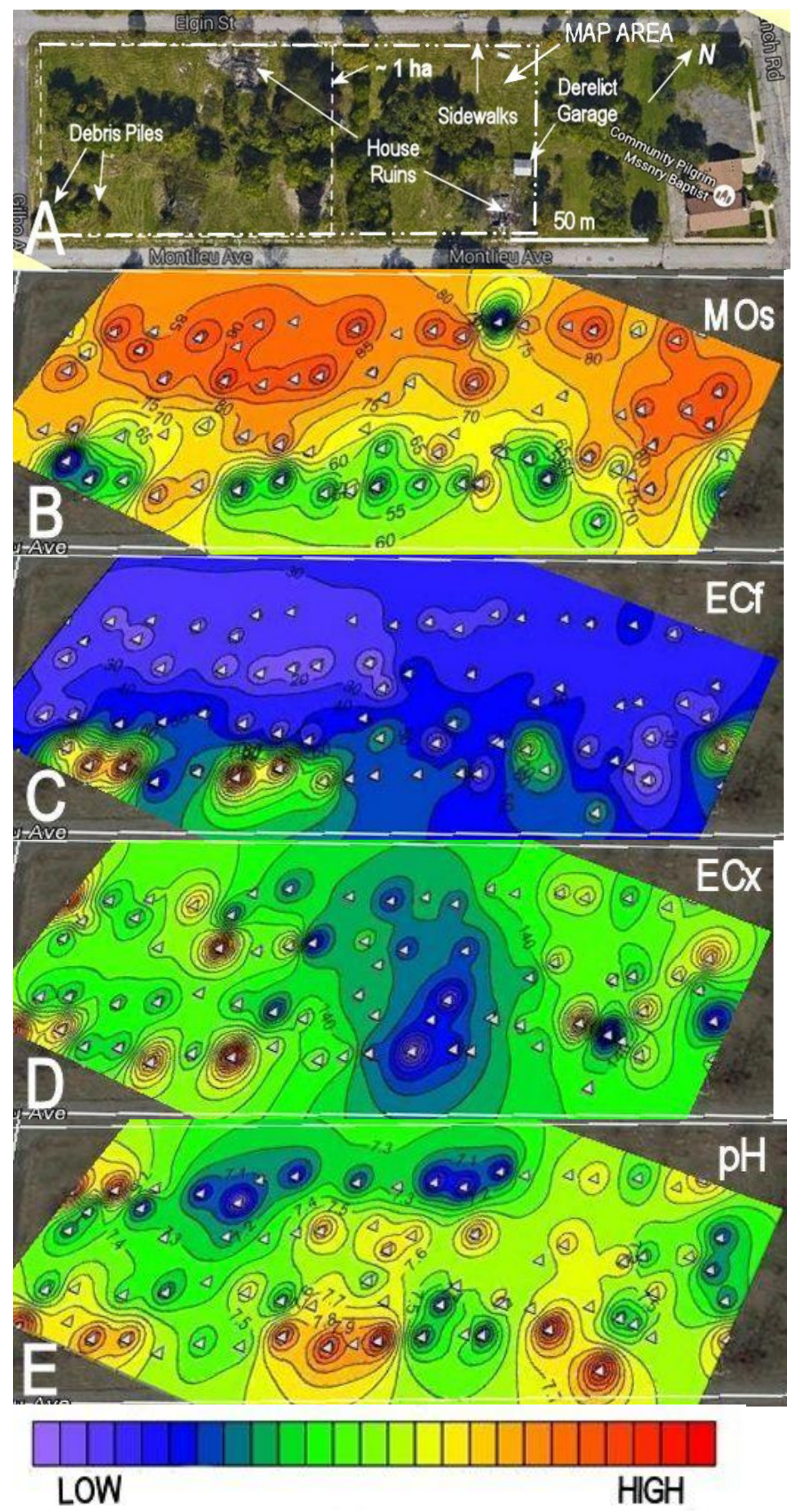



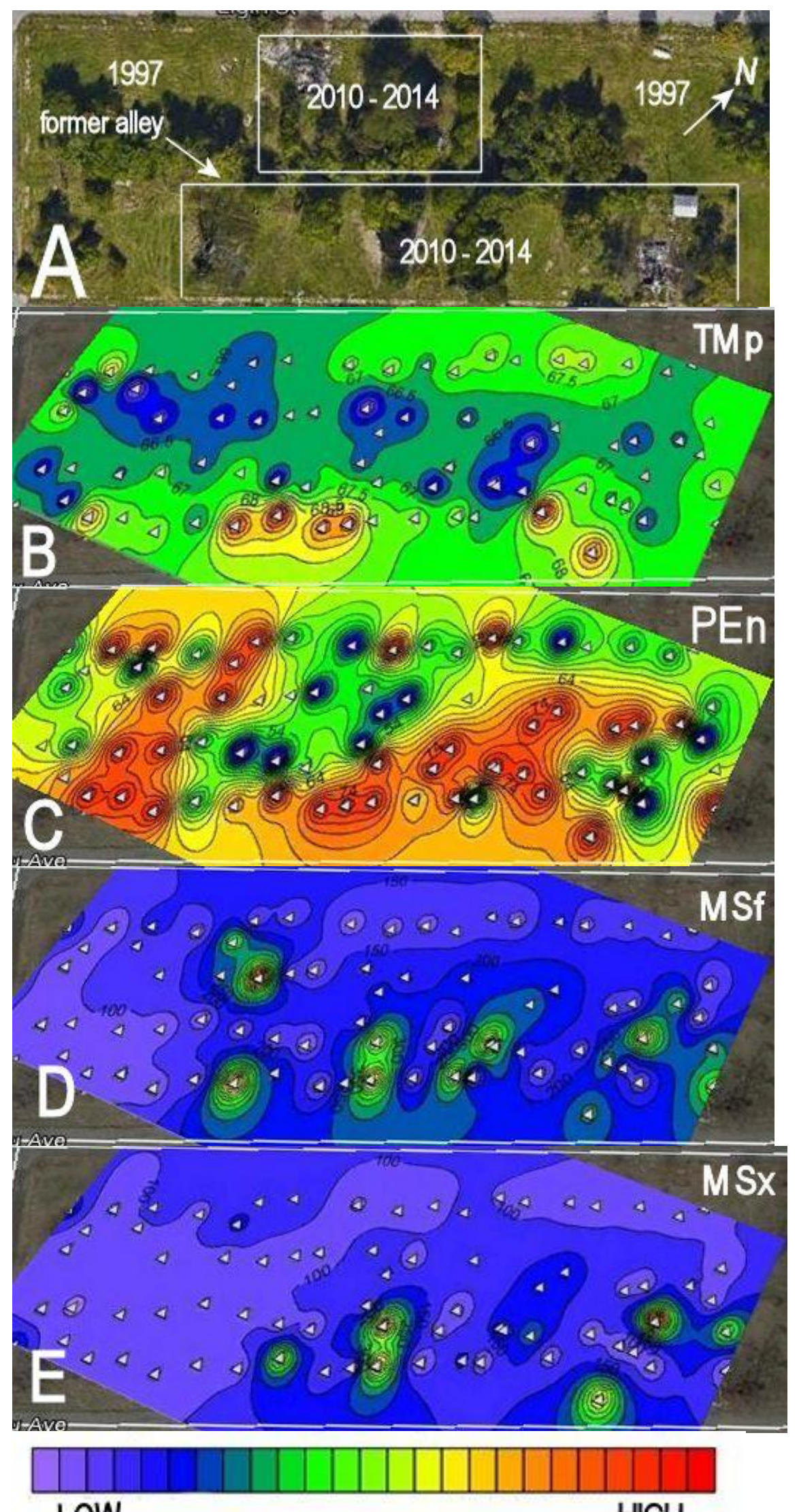


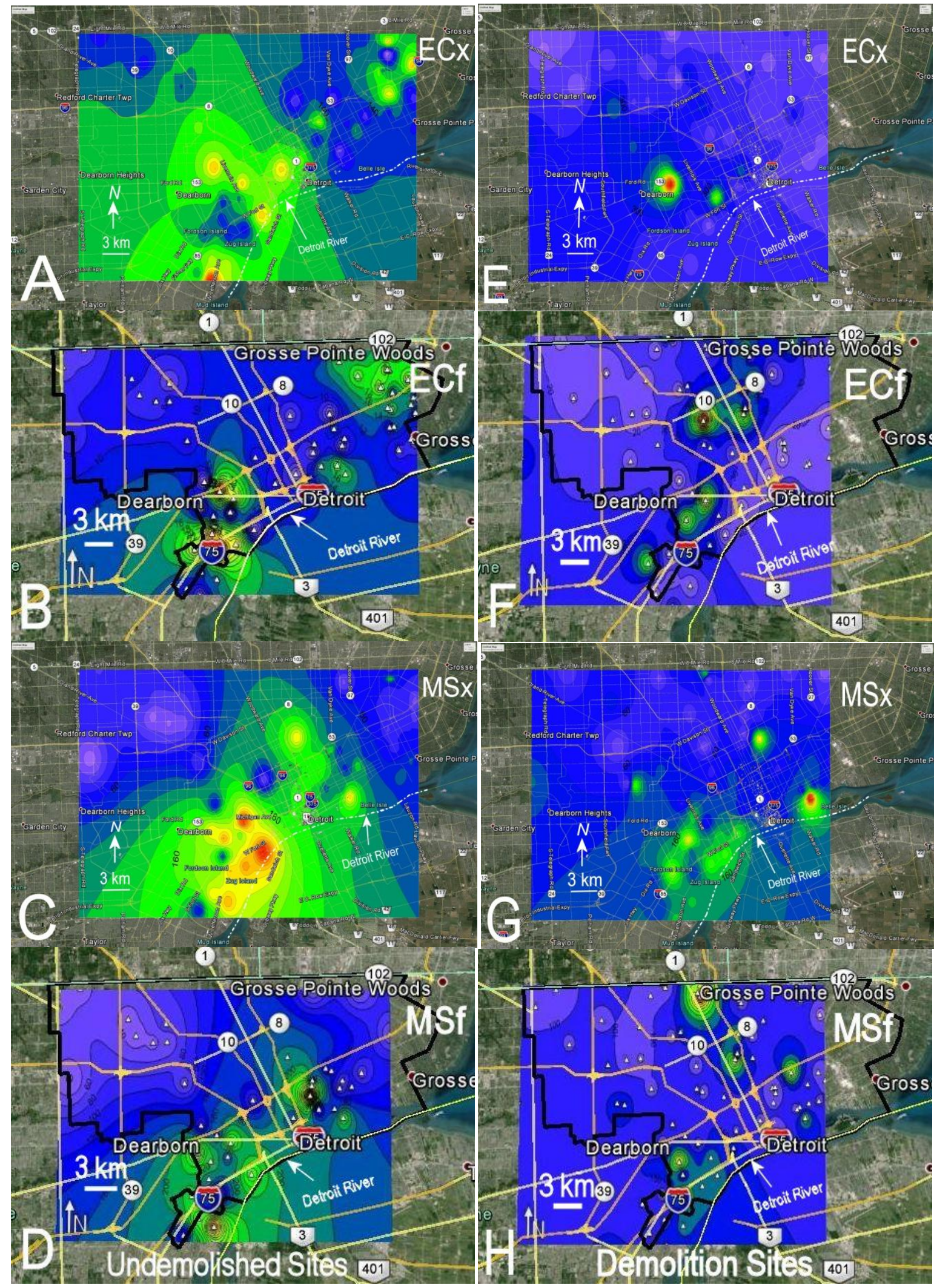



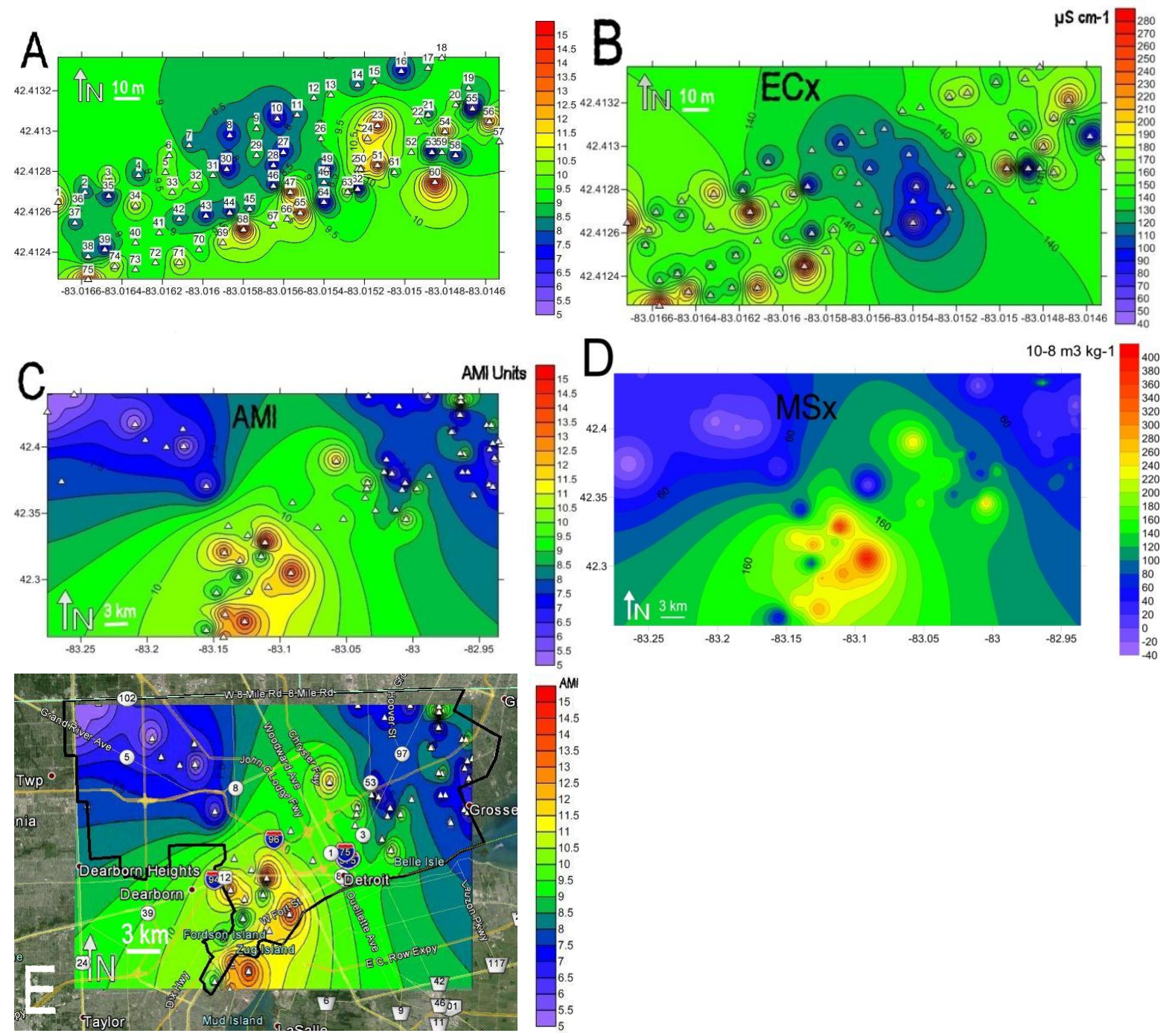